University of Nebraska - Lincoln

DigitalCommons@University of Nebraska - Lincoln

Faculty Publications from the Harold W. Manter Laboratory of Parasitology

$5-1998$

\title{
Preliminary Phylogenetic Analysis of Subfamilies of the Proteocephalidea (Eucestoda)
}

\author{
Amilcar Arandas Rego \\ Instituto Oswaldo Cruz \\ Alain de Chambrier \\ Switzerland Natural History Museum \\ Vladimira Hanzelová \\ Slovak Academy of Sciences \\ Eric P. Hoberg \\ United States Department of Agriculture, eric.hoberg@ars.usda.gov \\ Tomás Scholz \\ Academy of Sciences of the Czech Republic \\ See next page for additional authors
}

Follow this and additional works at: https://digitalcommons.unl.edu/parasitologyfacpubs

Part of the Parasitology Commons

Arandas Rego, Amilcar; de Chambrier, Alain; Hanzelová, Vladimira; Hoberg, Eric P.; Scholz, Tomás; Weekes, Peter; and Zehnder, Marc, "Preliminary Phylogenetic Analysis of Subfamilies of the Proteocephalidea (Eucestoda)" (1998). Faculty Publications from the Harold W. Manter Laboratory of Parasitology. 315. https://digitalcommons.unl.edu/parasitologyfacpubs/315

This Article is brought to you for free and open access by the Parasitology, Harold W. Manter Laboratory of at DigitalCommons@University of Nebraska - Lincoln. It has been accepted for inclusion in Faculty Publications from the Harold W. Manter Laboratory of Parasitology by an authorized administrator of DigitalCommons@University of Nebraska - Lincoln. 


\section{Authors}

Amilcar Arandas Rego, Alain de Chambrier, Vladimira Hanzelová, Eric P. Hoberg, Tomás Scholz, Peter Weekes, and Marc Zehnder 


\title{
Preliminary phylogenetic analysis of subfamilies of the Proteocephalidea (Eucestoda)*
}

\author{
Amilcar Arandas Rego ${ }^{1}$ (Chairman), Alain de Chambrier $^{2}$, Vladimira Hanzelová ${ }^{3}$, Eric \\ Hoberg $^{4}$, Tomás Scholz ${ }^{5}$, Peter Weekes ${ }^{6}$ \& Marc Zehnder ${ }^{7}$ \\ ${ }^{1}$ Instituto Oswaldo Cruz, Department of Helminthology, PO Box 926, 21045-900, Rio de Janeiro, Brasil (with \\ financial support of CNPq, Brasil) \\ ${ }^{2}$ Department of Invertebrates, Natural History Museum, PO Box 6434, 1211 Geneva 6, Switzerland \\ ${ }^{3}$ Institute of Parasitology, Slovak Academy of Sciences, Hlinkova 3, 04001 Kosice, Slovak Republic \\ ${ }^{4}$ United States Department of Agriculture, Agricultural Research Service, Biosystematics and National Parasite \\ Collection Unit, BARC East, Building 1180, 10300 Baltimore Avenue, Beltsville, Maryland 20705-2350, USA \\ ${ }^{5}$ Institute of Parasitology, Academy of Sciences of the Czech Republic, Branisovska 31, 37005 Ceské Budejovice, \\ Czech Republic \\ ${ }^{6}$ Institute of Environmental Science \& Research Limited, Communicable Disease Centre, Kenepuru Drive, PO Box \\ 50-348, Porirua, New Zealand \\ ${ }^{7}$ Institut de Zoologie, Université de Neuchâtel, E.-Argand 11, 2007 Neuchâtel, Switzerland
}

Accepted for publication 20th October, 1997

\begin{abstract}
Cladistic analysis based on comparative morphology was used to examine the subfamily-level relationships within the cestode order Proteocephalidea. A single most parsimonious tree $(70$ steps, $\mathrm{CI}=0.571 ; \mathrm{RC}=0.295 ; \mathrm{HI}=0.471)$ is consistent with monophyly for the Proteocephalidea and showed a relatively high consistency at the family level with the diagnosis of two major subclades. Unambiguous support for a Proteocephalidae subclade, including the Corallobothriinae, Proteocephalinae, Gangesiinae and Sandonellinae, and a Monticelliidae subclade, including the Marsypocephalinae, Zygobothriinae, Monticelliinae, Rudolphiellinae, Ephedrocephalinae and Othinoscolecinae was evident. Two subfamilies, the Acanthotaeniinae (historically in the Proteocephalidae) and Nupeliinae (historically in the Monticelliidae), were however, basal to all other subfamilies, indicating that neither family as currently conceived is monophyletic. Trees one or two steps longer, however, would be consistent with monophyly for the Proteocephalidae and Monticelliidae (excluding Acanthotaeniinae) or would result in the monophyly for both families, including all respective subfamilies congruent with current concepts for systematics of the order. Zoogeographical analysis demonstrated a strong Gondwanan association; proteocephalideans originated in Africa, with subsequent development linking Africa and South America. Colonisation of the Northern Hemisphere by proteocephalid subfamilies, the Proteocephalinae, Corallobothriinae and Gangesiinae, was secondary. Analysis of parasite-host relationships indicated that the basal hosts for the Proteocephalidea are equivocal; siluriform teleosts were, however, the basal hosts for the Nupeliinae + the Monticelliidae and Proteocephalidae subclades and an extensive co-evolutionary history with this host group is postulated. Independent colonisation events of reptilians by species of the Proteocephalinae and Acanthotaeniinae, non-siluriform teleosts associated with the Sandonellinae and some Proteocephalinae, and amphibians by some Proteocephalinae, are recognised. Some points which should be considered for further development of the systematics of the group are proposed, with special emphasis given to thorough morphological descriptions and investigations of life-cycles.
\end{abstract}

* A report of results of phylogenetic analyses conducted during the 2nd International Workshop for Tapeworm Systematics, Lin- coln, Nebraska, 2-6 October 1996; E.P. Hoberg, S.L. Gardner and R.A. Campbell, organisers. Contributions edited by E.P. Hoberg. 


\section{Introduction}

The tapeworms of the order Proteocephalidea are parasites of freshwater fish, amphibians and reptiles (Freze, 1965; Rego, 1994). In excess of 300 species have been described in two families, the Proteocephalidae and Monticelliidae, that contain 12 subfamilies and 46 genera. More than one half of the genealogical diversity of the group is limited to species parasitising freshwater fishes, principally siluriforms, from South American (Schmidt, 1986; Rego, 1994).

Subsequent to the description of the first species of the Proteocephalidea, Taenia (= Proteocephalus) percae by Müller (1780), the first complex account on the group was provided by La Rue $(1911,1914)$. He erected two families, the Proteocephalidae with the genera Proteocephalus Weinland, 1858, Corallobothrium Fritsch, 1886, Crepidobothrium Monticelli, 1899, Acanthotaenia von Linstow, 1903 and Ophiotaenia La Rue, 1911; and the Monticelliidae, to accommodate the species Tetracotylus (= Monticellia) coryphicephala Monticelli, 1891. Later, Woodland (1933a,b,c, 1934a,b,c, 1935a,b,c) described a number of species and genera from South American siluriform fishes, mainly those placed into the Monticelliidae.

Freze (1965) presented in his monograph of the Proteocephalidea a new arrangement of the group. He recognised three families: (1) Proteocephalidae La Rue, 1911 with subfamilies Proteocephalinae, Corallobothriinae Freze, 1965, Gangesiinae Mola, 1929, Paraproteocephalinae Freze, 1963, Sandonellinae Khalil, 1960, and Zygobothriinae Woodland, 1933; (2) Ophiotaeniidae Freze, 1963 with the Ophiotaeniinae and Acanthotaeniinae Freze, 1963; and (3) Monticelliidae La Rue, 1911 with the Monticelliinae, Endorchiinae Woodland, 1934, Ephedrocephalinae Mola, 1929, Marsypocephalinae Woodland, 1933, Othinoscolecinae Woodland, 1933 (syn. Peltidocotylinae Woodland, 1934) and Rudolphiellinae Woodland, 1935. Brooks (1978a), however, synonymised the Ophiotaeniidae with the Proteocephalidae; this synonymy has widely been accepted by other workers.

Twenty years later, Schmidt (1986) primarily mirrored the classification of Freze (1965), but did not retain the family Ophiotaeniidae and placed the Zygobothriinae in the Monticelliidae. Schmidt (1986) recognised two families, the Proteocephalidae and Monticelliidae, the former comprising the Gangesiinae, Prosobothriinae Yamaguti 1959 (now placed to the order Lecanicephalidea Wardle \& McLeod, 1952 - see Euzet, 1994), Sandonellinae, Coral- lobothriinae, Acanthotaeniinae, Proteocephalinae and Marsypocephalinae; the latter including the Monticelliinae, Zygobothriinae, Endorchiinae, Ephedrocephalinae, Othinoscolecinae Woodland, 1934 (syn. Peltidocotylinae) and Rudolphiellinae.

Rego (1994) presented a similar system in his review of the Proteocephalidea. A new subfamily, Nupeliinae Pavanelli \& Rego, 1991, was placed into the Monticelliidae. The same author (Rego 1995) proposed completely different classification of the group, retaining one family, the Proteocephalidae, and suppressing the Monticelliidae to subfamily level.

Phylogenetic analysis of the Proteocephalidea based on cladistic assessment of morphological characters has been performed by Brooks (1978a,b, 1995), Brooks \& Rasmussen (1984), Brooks et al. (1991) and Brooks \& McLennan (1993). Brooks (1978b) conducted the first analysis of morphological, zoogeographical and host relationships among genera of the order. The Marsypocephalinae was suppressed, being grouped within the Corallobothriinae. This classification recognised the Proteocephalidae with the Corallobothriinae, Sandonellinae, Proteocephalinae, Acanthotaeniinae and Gangesiinae; and the Monticelliidae with the Zygobothriinae, Monticelliinae and Othinoscolecinae (syn. Peltidocotylinae).

Brooks \& Rasmussen (1984) revised the classification of the Monticelliidae on the basis of reinterpretation of some characters listed previously by Brooks (1978b). In contrast to earlier studies, some degree of parallel evolution was found in the majority of morphological characters. The authors pointed out the need to revise the taxonomy of the Monticelliidae in order to be more consistent with their phylogeny.

Brooks et al. (1991) postulated that proteocephalideans might be polyphyletic and that the Monticelliidae might not be monophyletic, because the most important diagnostic feature, the cortical vitellarium, is plesiomorphic. In this analysis, which concentrated on the relationships among the major lineages of the Eucestoda, the Proteocephalidae were divided into two branches. These were diagnosed by the presence/absence of a cysticercoid in the life-cycle, and the Gangesiinae were considered to be related and basal to Cyclophyllidea due to the presence of an armed rostellum.

Brooks (1995) presented a new classification of monticelliid genera based on the phylogenetic tree of this family. This classification resulted in synonymy of numerous genera, e.g. Endorchis Woodland, 1934, Gibsoniela Rego, 1985 and Nupelia Pavanelli \& Rego, 
1991 with Nomimoscolex Woodland, 1934; Ephedrocephalus Diesing, 1850 and Othinoscolex Woodland, 1933 with Rudolphiella Fuhrmann, 1916; Peltidocotyle Diesing, 1850 Choanoscolex La Rue, 1911, Goezeella Fuhrmann, 1916 and Jauella Rego \& Pavanelli, 1985 with Spatulifer Woodland, 1934.

The analyses by Brooks set the foundation for detailed study of the phylogeny of the Proteocephalidea and constitute a set of testable phylogenetic hypotheses for relationships among the genera and subfamilies. Interpretations presented by Brooks and coworkers were limited, however, by the uneven quality of comparative morphological and biological data in the literature. A shortage of reliable and complete data for many taxa, mainly those from South American fishes described by Woodland between 1933 and 1935 (cf. de Chambrier \& Vaucher, 1997) makes it difficult to perform a consistent phylogenetic analysis of the group at the generic-level or to assess the phylogenetic importance of individual characters. In addition, there is a considerable gap in data on the life-cycles of most proteocephalideans and no information has been provided on the life-cycle of any member of the family Monticelliidae.

In order to evaluate the current stage of knowledge of the systematics of the Proteocephalidea, a phylogenetic analysis of the group was performed by the present authors. The present study is based on critical observations on taxa, mainly those from South America (see numerous papers by de Chambrier, Rego and co-authors). It must be emphasised, however, that it reflects the present state of knowledge, which is still far from being satisfactorily complete. For this reason, the present analysis is limited to the study of relationships among subfamilies of the Proteocephalidea, taking a top down approach to assessment of genealogical diversity (see Hoberg et al., 1997). Consistent with all phylogenetic studies, this will be open to critical and continued evaluation with the advent of a more complete database for comparative morphology and biology.

The main part of the analysis was carried out by members of the Proteocephalidea group (chairman A.A. Rego) during the Workshop on Tapeworm Systematics in Lincoln, Nebraska, October 2-6, 1996. Corrections and re-interpretation of some characters, based mainly on the re-examination of new material, analysis of amended data and final editing of the manuscript were made subsequently and are the responsibility of A. de Chambrier, E. Hoberg and T. Scholz.

\section{Materials and methods}

Relationships among proteocephalidean subfamilies were analysed using phylogenetic systematics (Hennig, 1950, 1966; Wiley et al., 1991). Characters were analysed with the program "Phylogenetic Analysis Using Parsimony", Version 3.05 (PAUP) (Swofford, 1993); further analyses of characters, host association and biogeography were conducted using MacClade Version 3.05 (Maddison \& Maddison, 1993).

\section{Specimens examined}

Taxonomy and classification of subfamilies considered here is based on the system proposed by Rego (1994). The analysis was based on critical observations of features in most proteocephalidean genera studied by the present authors: A.A. Rego and A. de Chambrier in South America (see Rego et al., 1974; de Chambrier \& Vaucher, 1984, 1992, 1994, 1997; Rego, 1987, 1991, 1994; de Chambrier, 1987, 1988, 1989a,b, 1990; Rego \& Pavanelli, 1990, 1991,1992; de Chambrier et al., 1992, 1996; de Chambrier \& Paulino, 1997; de Chambrier \& Rego, 1994, 1995; Rego \& de Chambrier, 1995; Scholz et al., 1996) and V. Hanzelová \& T. Scholz in the Holarctic (Scholz, 1989, 1991, 1993; Scholz \& Ergens, 1990; Hanzelová \& Spakulová, 1992; Hanzelová \& Scholz, 1992, 1993; Scholz \& Cappellaro, 1993; Scholz \& Hanzelová, 1994; Hanzelová et al., 1995a,b; Scholz et al., 1995, 1997).

Results of the studies of extensive material of proteocephalideans from Amazonia (Brazil) and Paraguay, part of which has yet to be published (A. de Chambrier and A.A. Rego), were also used for analysis. In addition, some type and voucher specimens of Woodland's material were examined by one of the authors (A. de Chambrier); vouchers of the following taxa recently have been examined: Sandonella sandoni (MHNG 18155 INVE), Kapsulotaenia sp. (Harold W. Manter Laboratory, University of Nebraska Museum, Lincoln, Coll. No. 33942), Silurotaenia siluri and Gangesia parasiluri (both Institute of Parasitology, České Budějovice, Coll. Nos. C-52 and C-125, respectively).

\section{Character analysis}

Characters used in the analysis were derived mainly from comparative morphological and taxonomic studies of the present authors (see above). In some groups, we relied on morphological data derived from the extensive literature; it is recognised, however, that some 
characters might have been described incorrectly in their original descriptions. Polarisation of characters was based on comparisons to a taxonomic outgroup (Maddison et al., 1984; Wiley et al., 1991). The Tetraphyllidea (see Euzet, 1994) was the primary outgroup, as it is a putative paraphyletic taxon basal to the ingroup as determined by results of analyses at the ordinal level among the Eucestoda (Hoberg et al., 1997). Characters of the outgroup were taken from data provided by Euzet (1994). In addition, some details regarding individual characters and putative plesiomorphy or apomorphy were discussed personally with L. Euzet during the Workshop.

In subfamilies containing multistate taxa (genera or species with both the primitive and derived state, mainly in Proteocephalinae and Zygobothriinae), we chose a conservative approach with respect to coding for polymorphism. We recognise that coding for polymorphism can result in ambiguity and potentially may lead to incorrect reconstructions (see Maddison $\&$ Maddison, 1993). Thus, few characters and taxa are regarded as polymorphic. In most cases, explicit decisions have been made relative to coding a specific attribute as plesiomorphic or apomorphic within a given taxon. As a generality, if the derived state occurred in the subfamily, then coding was considered apomorphic to recognise acquisition of a specific state in at least some genera (or species) within a particular subfamily (see Hoberg \& Lichtenfels, 1994).

Some characters, previously used for phylogenetic analysis (e.g. Brooks, 1978b), were not used in the present study because they were considered to have minimal information or require more detailed evaluation; e.g. thickness of the longitudinal musculature (inconspicuous versus well developed - see Brooks $\&$ Rasmussen, 1984), formation of the uterus (preformed versus not preformed in mature proglottides Freze, 1965); structure of the ovary (follicular versus non-follicular - Brooks, 1978b); orientation of uterine branches (lateral versus antero-posterior - Brooks, 1978 b), etc. A summary of the 27 characters, representing 38 character states, is presented below and in a numerical matrix (Table I). Plesiomorphic states are coded as 0, apomorphic as 1, 2, or 3. Analyses with PAUP were conducted with Branch and Bound and all multistate characters were run as unordered; results are presented a phylogenetic tree with associated statistics including the Consistency Index (CI), Homoplasy Index (HI) and Rescaled Consistency Index (RC) as specified by Swofford (1993).

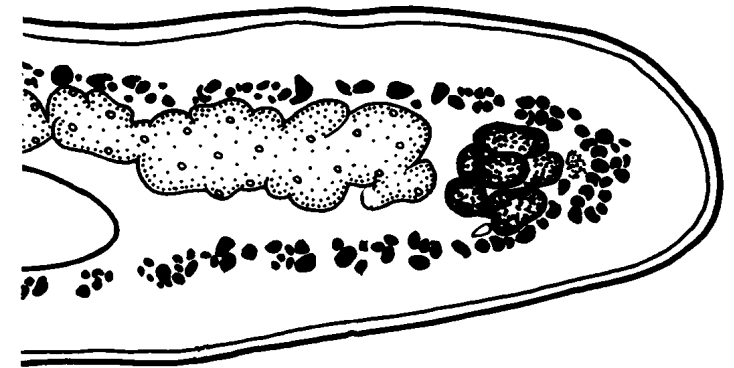

1

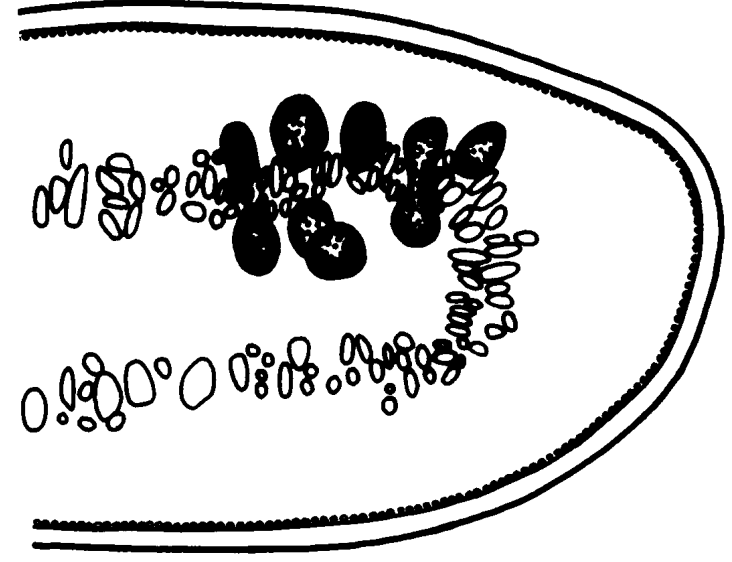

2

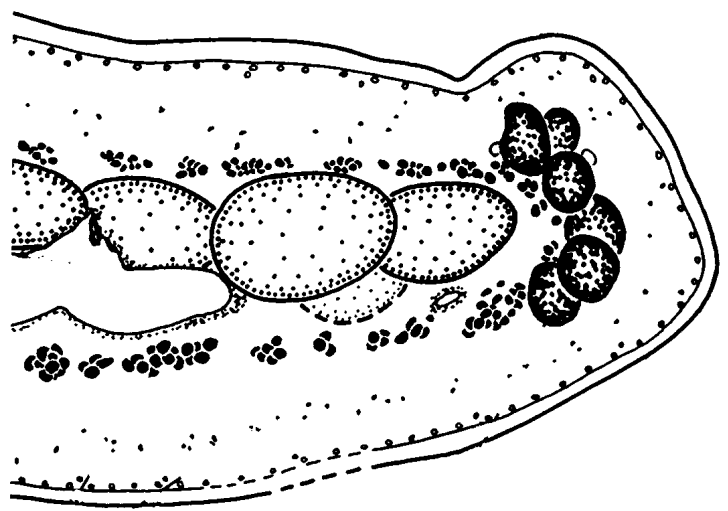

3

Figures 1-3. Position of vitelline follicles: 1. medullary, Proteocephalus soniae de Chambrier \& Vaucher, 1994 (after de Chambrier \& Vaucher, 1994); 2. paramuscular, P. paraguayensis (Rudin, 1917) (after de Chambrier, 1990); 3. cortical, Nomimoscolex piraeeba Woodland, 1934 (after de Chambrier \& Vaucher, 1997). 
Table I. Character matrix for the subfamilies of the Protocephalidea and the Tetraphyllidea.

\begin{tabular}{|c|c|c|c|c|c|c|c|c|c|c|c|c|c|c|c|c|c|c|c|c|c|c|c|c|c|c|c|}
\hline \multirow[b]{2}{*}{ Subfamilies } & \multicolumn{27}{|c|}{ Character } \\
\hline & 1 & 2 & 3 & 4 & 5 & 6 & 7 & 8 & 9 & 10 & 11 & 12 & 13 & 14 & 15 & 16 & 17 & 18 & 19 & 20 & 21 & 22 & 23 & 24 & 25 & 26 & 27 \\
\hline Corallobothriinae & 0 & 0 & 0 & 0 & 2 & 0 & 1 & 0 & 0 & 0 & 1 & 0 & 0 & 3 & 0 & 1 & 0 & 0 & 0 & 1 & 0 & 0 & 1 & 1 & 0 & 0 & 0 \\
\hline Marsypocephalinae & 0 & 0 & 0 & 2 & 0 & 0 & 1 & 0 & $?$ & 1 & 1 & 0 & 0 & 3 & 1 & 0 & 0 & 0 & 0 & 1 & 0 & 0 & 0 & 1 & 0 & 0 & 1 \\
\hline Sandonellinae & 0 & 2 & 0 & 0 & 0 & 0 & 1 & 0 & $?$ & 1 & 1 & 0 & 1 & $1 \& 2$ & 0 & 0 & 0 & 0 & 0 & 0 & 0 & 1 & 1 & 1 & 0 & 0 & 0 \\
\hline Proteocephalinae & 1 & 0 & 0 & 0 & 1 & 0 & 1 & $0 \& 1$ & 0 & 0 & 2 & 0 & 0 & 3 & 0 & 0 & 1 & 1 & 0 & 0 & 0 & 0 & 1 & 1 & 1 & 0 & 1 \\
\hline Gangesiinae & 0 & 0 & 0 & 0 & 0 & 0 & 1 & 0 & 0 & 0 & 1 & 0 & 0 & 3 & 0 & 0 & 0 & 0 & 0 & 0 & 1 & 0 & 0 & 1 & 1 & 0 & 0 \\
\hline Acanthotaeniinae & 0 & 0 & 0 & 0 & 2 & 0 & 2 & 0 & $?$ & 1 & 2 & 0 & 0 & $0 \& 1$ & 0 & 0 & 0 & 0 & 0 & 0 & 0 & 0 & 0 & 0 & 1 & 1 & 0 \\
\hline Zygobothriinae & 2 & 0 & 1 & 0 & 2 & 2 & 1 & 0 & 1 & 0 & 2 & 1 & 1 & 3 & 1 & 1 & 0 & 1 & 1 & 1 & 0 & 0 & 1 & 0 & 1 & 0 & 1 \\
\hline Nupeliinae & 2 & 0 & 1 & 1 & 0 & 2 & 1 & 0 & 0 & 1 & 0 & 0 & 0 & 0 & 0 & 0 & 0 & 0 & 0 & 0 & 0 & 0 & 0 & 1 & 0 & 0 & 0 \\
\hline Rudolphiellinae & 2 & 0 & 1 & 0 & 0 & 0 & 1 & 0 & 0 & 1 & 2 & 0 & 0 & 3 & 1 & 1 & 0 & 0 & 0 & 0 & 0 & 0 & 0 & 1 & 0 & 0 & 0 \\
\hline Monticelliinae & 2 & 0 & 2 & 2 & 0 & 1 & 1 & 2 & 1 & 0 & 1 & 0 & 0 & 3 & 1 & 1 & 0 & 1 & 0 & 0 & 0 & 0 & 0 & 1 & 0 & 0 & 1 \\
\hline Ephedrocephalinae & 2 & 1 & 0 & 2 & 0 & 0 & 1 & 0 & 0 & 1 & 0 & 0 & 0 & 2 & 1 & 1 & 0 & 0 & 0 & 0 & 0 & 0 & 1 & 1 & 0 & 0 & 1 \\
\hline Othinoscolecinae & 2 & 0 & 0 & 2 & 0 & 1 & 1 & 0 & 0 & 1 & 0 & 0 & 0 & 2 & 1 & 1 & 0 & 1 & 0 & 1 & 0 & 0 & 1 & 1 & 0 & 0 & 1 \\
\hline Tetraphyllidea & 0 & 0 & 0 & 0 & 0 & 0 & 0 & 0 & 0 & 0 & 0 & 0 & 0 & 0 & 0 & 1 & 0 & 1 & 0 & 0 & 0 & 0 & 0 & 0 & 0 & 0 & 0 \\
\hline
\end{tabular}

\section{Results}

\section{Characters}

(1) Position of vitelline follicles (Figures 1-3). Three states: $0=$ medullar; 1 = paramuscular; $2=$ cortical. Paramuscular position of vitelline follicles is defined according to de Chambrier (1990): follicles encircle bundles of the longitudinal musculature, with some follicles reaching to the cortex and some follicles to the medulla (Figure 2).

(2) Topography (distribution) of vitelline follicles (Figures 4-6). Three states: $0=$ two lateral fields; 1 $=$ scattered throughout proglottis forming one ventral field; 2 = compact, posterior to ovary. State 1 is present in Ephedrocephalus microcephalus Diesing, 1850 (Ephedrocephalinae) (Figure 5); state 2 in Sandonella sandoni (Lynsdale 1960) (Sandonellinae) (Figure 6).

(3) Position of ovary. Three states: $0=$ medullar; 1 = originally medullary, developing cortically; $2=$ cortical. State 1 is present in the genera Endorchis Woodland, 1934 and Gibsoniela Rego, 1984 and in Nomimoscolex admonticellia (Woodland, 1934) (all Zygobothriinae) (Figure 7).

(4) Position of testes. Three states: $0=$ medullar; 1 = paramuscular; 2 = cortical. State 1 has been observed only in the Nupeliinae (Pavanelli \& Rego, 1991; Figure 8).

(5) Position of testicular fields (Figures 9-11). Three states: $0=$ one field; $1=$ two fields connected anteriorly; 2 = two distinctly separated fields.
(6) Position of uterus. Three states: $0=$ medullar; 1 = cortical; 2 = originally cortical, developing medullarly. State 0 is the most common; state 1 is present in the Monticelliinae and Othinoscolecinae; state 2 in some Proteocephalus (Proteocephalinae), Zygobothrium Diesing, 1850, Endorchis Woodland, 1934 and Nomimoscolex Woodland, 1934 (all Zygobothriinae).

(7) Original shape of uterus. Three states: $0=$ saccate, without lateral expansions (diverticula); 1 = saccate, with lateral expansions (diverticula); 2 = forming capsules. Capsules, present in Kapsulotaenia Freze, 1965 (Acanthotaeniinae), are formed by eggs grouped together, covered with a thin-walled membrane; the capsules are within the lumen of the uterine diverticula connected with the uterine stem.

(8) Egg structure (Figures 12-14). Three states: 0 = egg spherical to oval, external hyaline membrane present; 1 = internal polar circle-like structures present; 2 = polar filaments present. State 1 is present in eggs of Crepidobotrium eirasi Rego \& de Chambrier, 1995 (Proteocephalinae; Figure 13); state 2 in Goezeella siluri Fuhrmann, 1916 (Monticelliinae) and Proteocephalus renaudi de Chambrier \& Vaucher, 1994 (Proteocephalinae; Figure 14).

(9) Embryonation of eggs. Two states: $0=\mathrm{em}-$ bryonated when laid (= ovoviviparus); 1 = unembryonated when laid (= oviparous; see Brooks et al., 1991).

(10) Vaginal sphincter. Two states: $0=$ present; 1 $=$ absent . The vaginal sphincter is considered to be the 

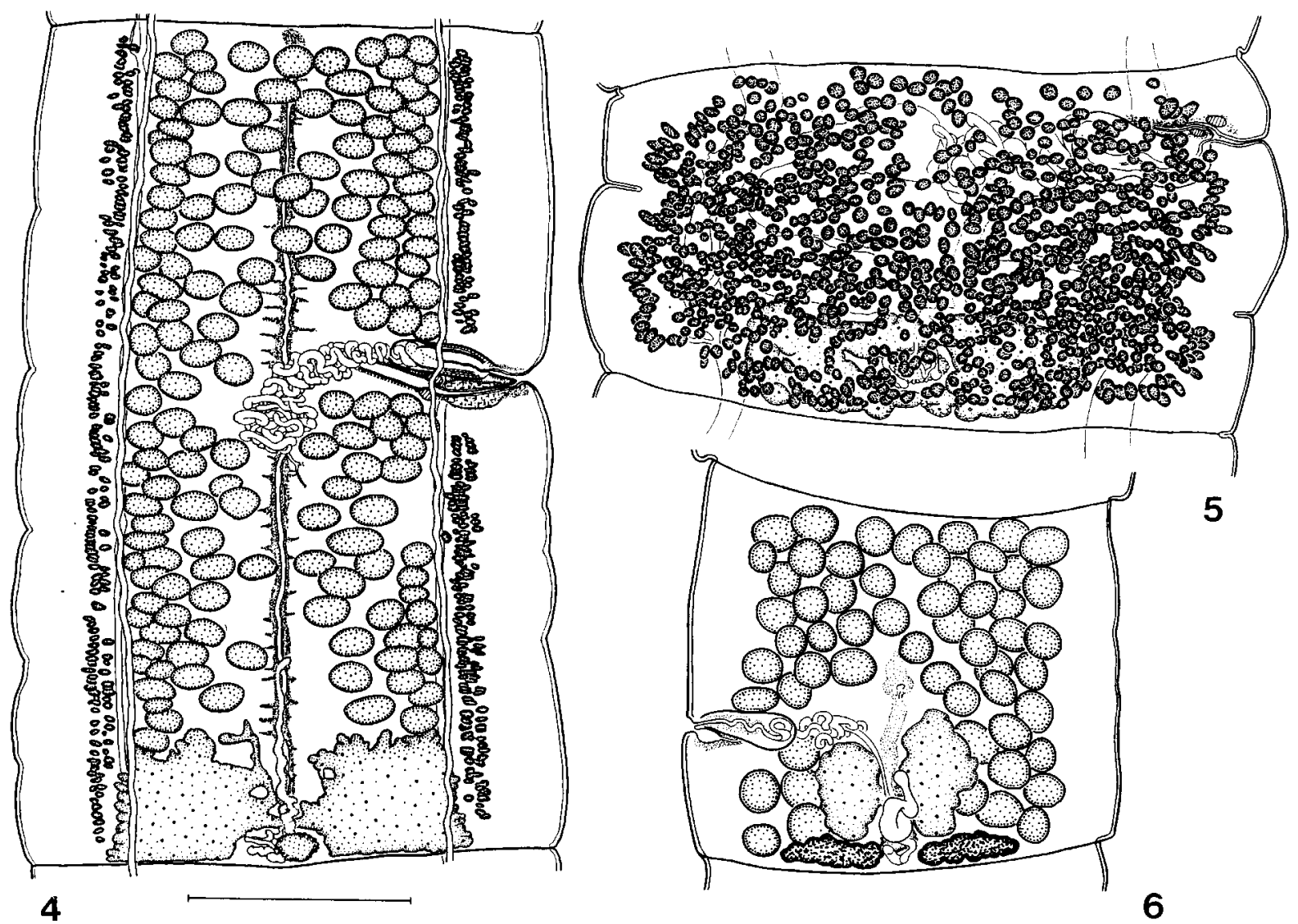

Figures 4-6. Topography (distribution) of vitelline follicles: 4. two lateral fields, Proteocephalus renaudi de Chambrier \& Vaucher, 1994 (after de Chambrier \& Vaucher, 1994); 5. scattered throughout proglottis forming one ventral field, Ephedrocephalus microcephalus Diesing, 1850 (original); 6. compact, posterior to ovary, Sandonella sandoni (Lynsdale, 1963) (original). Scale-bars: 4,5, 500 $\mu \mathrm{m} ; 6,250 \mu \mathrm{m}$.

circular muscular sphincter surrounding the terminal (distal) part of the vagina (Figure 15).

(11) Position of vagina relative the to cirrus-sac. Three states: $0=$ anterior; $1=$ posterior; $2=$ alternating.

(12) Genital pore. Two states: $0=$ alternating irregularly; 1 = unilateral. The unilateral position of the genital pore is represented by some Amphoteromorphus spp. (Zygobothriinae; see de Chambrier \& Vaucher, 1997).

(13) Type of proglottides. Two states: $0=$ acraspedote; 1 = craspedote.

(14) Shape of mature proglottides. Four states: $0=$ longer than wide; 1 = quadrate; 2 = wider than long; 3 $=$ variable.

(15) Transverse tegumental wrinkles. Two states: 0 = absent; 1 = present; (Figure 17). State 1 is observed in the Marsypocephalinae and in all subfamilies referred to the Monticelliidae. Tegumental wrinkles which are not artifacts of inappropriate fixation (contraction of worms) should be considered.

(16) Metascolex. Two states: $0=$ absent; $1=$ present. Several types of the metascolex have been recognised by different authors (e.g. Brooks \& Rasmussen, 1984; Rego, 1995; de Chambrier \& Paulino, 1997). There is however a high degree of intraspecific variation of this feature. The shape of the metascolex may be dependent on fixation (see Rego \& Pavanelli, 1985 for Megathylacus brooksi Rego \& Pavanelli, 1985 and Scholz \& Cappellaro, 1993 for Corallobothrium parafimbriatum Befus \& Freeman, 1973 - both Corallobothriinae) and there may be forms that are intermediate to specific types of metascoleces (i.e. in Choanoscolex abscisus (Riggenbach, 1896) - Monticelliinae). Consequently, only two states (presence versus absence) are now considered until the various forms of the metascolex are clearly defined and distinguished. 

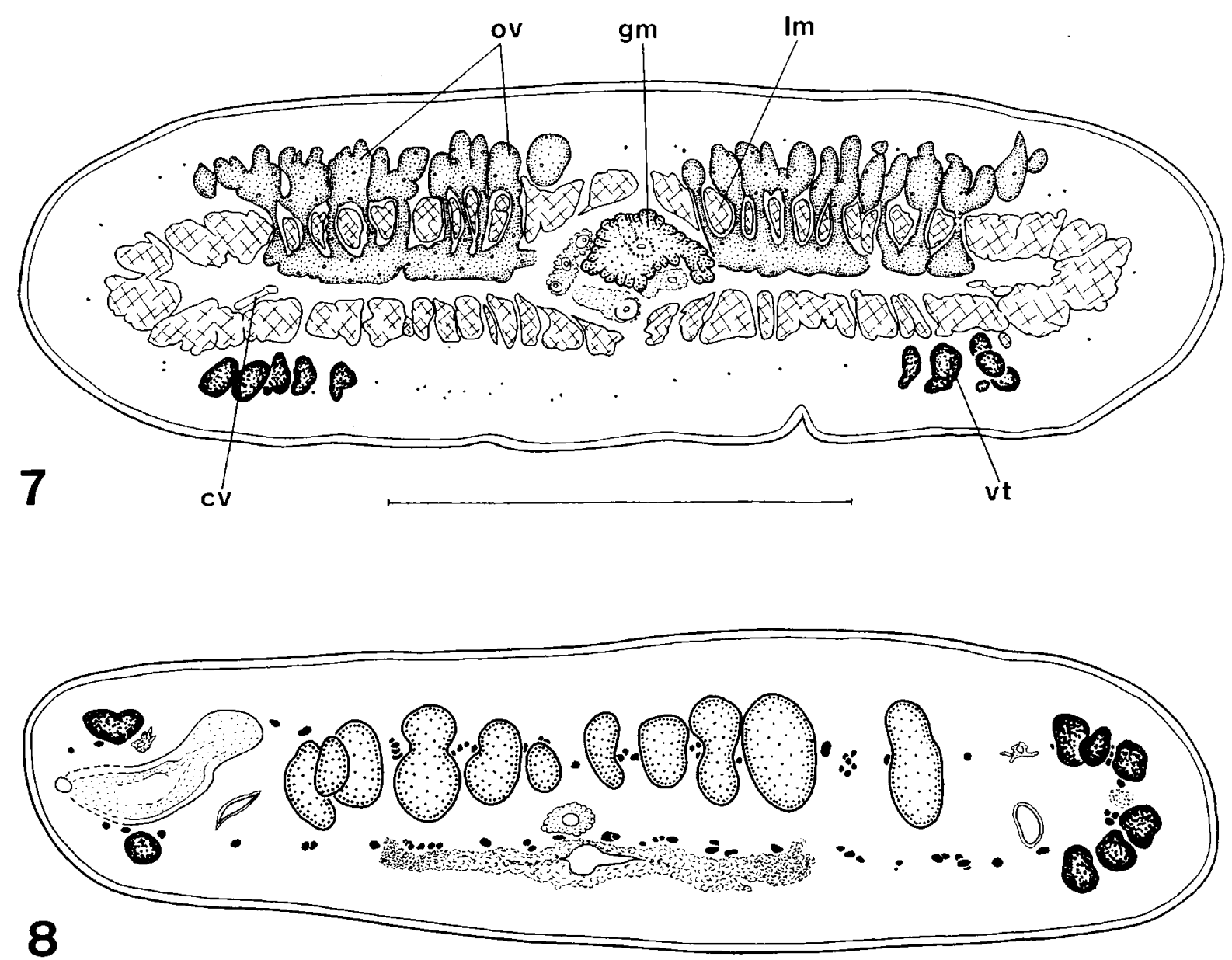

Figures 7-8. Position of ovary: originally medullary, developing cortically. Endorchis piraeeba Woodland, 1934 (after de Chambrier \& Vaucher, 1997). 8 Paramuscular position of testes, Nupelia portoriquensis Pavanelli \& Rego, 1991 (original). Abbreviations: cv, ventral osmoregulatory canal; gm, Mehlis' gland; lm, internal longitudinal musculature; ov, ovary outgrowth; vt, vitelline follicles. Scale-bars: 7,8, $500 \mu \mathrm{m}$.

(17) Apical organ. Three states: $0=$ absent; $1=$ muscular; 2 = glandular. State 1 is present in some Proteocephalus spp.; state 2 in Proteocephalus glanduliger (Janicki, 1928) and P. joanae de Chambrier \& Paulino, 1997 (Proteocephalinae), Jauella glandicephalus Rego \& Pavanelli, 1985 (Othinoscolecinae = Peltidocotylinae), Nomimoscolex piraeeba Woodland, 1934 (Zygobothriinae), etc. (Fuhrmann, 1933; Rego \& Pavanelli, 1985; de Chambrier \& Vaucher, 1997; de Chambrier \& Paulino, 1997).

(18) Sucker structure. Two states: $0=$ spherical; $1=$ other forms. State 1 is present in the proteocephaline genera Crepidobothrium Monticelli, 1900 and Deblocktaenia Odening, 1963 in some Zygobothriinae, Othinoscolecinae (syn. Peltidocotylinae) and Monticelliinae.
(19) Auricular (papilla-like) projections on suckers. Two states: $0=$ absent; $1=$ present. State 1 is presented in the genera Harriscolex Rego, 1987 and Houssayela Rego, 1987 and the species Nomimoscolex alovarius Brooks \& Deardorff, 1980 (all Zygobothriinae).

(20) Distal sphincter on suckers. We consider that this structure is not a true sphincter but merely acting as one (see de Chambrier \& Rego, 1995). Two states: $0=$ present; $1=$ absent. State 0 is present in the genera Marsypocephalus Weld, 1861 (Marsypocephalinae), Megathylacus Woodland, 1934, Megathylacoides Jones, Kerley \& Sneed, 1956 (Corallobothriinae), Zygobothrium Diesing, 1850 (Zygobothriinae), Mariauxiella de Chambrier \& Rego, 1995 $($ Othinoscolecinae $=$ Peltidocotylinae $)($ Figure 16) . 

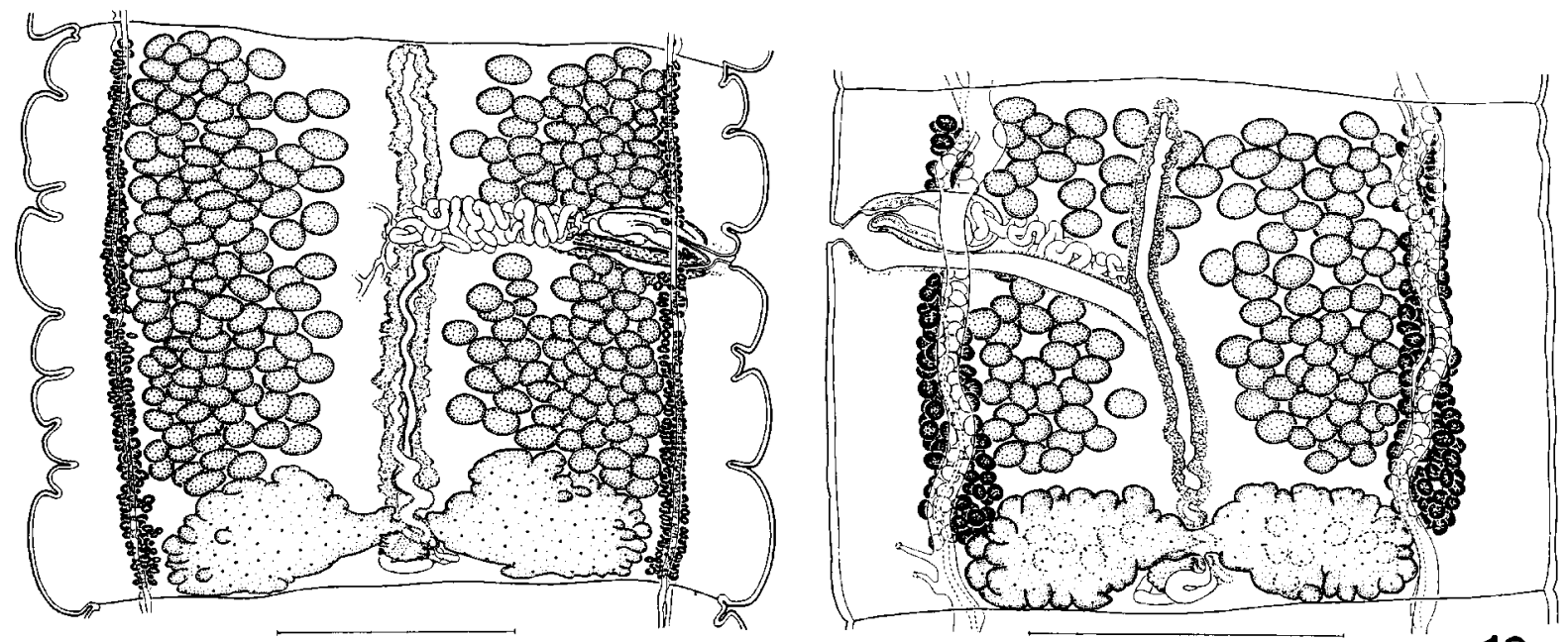

9

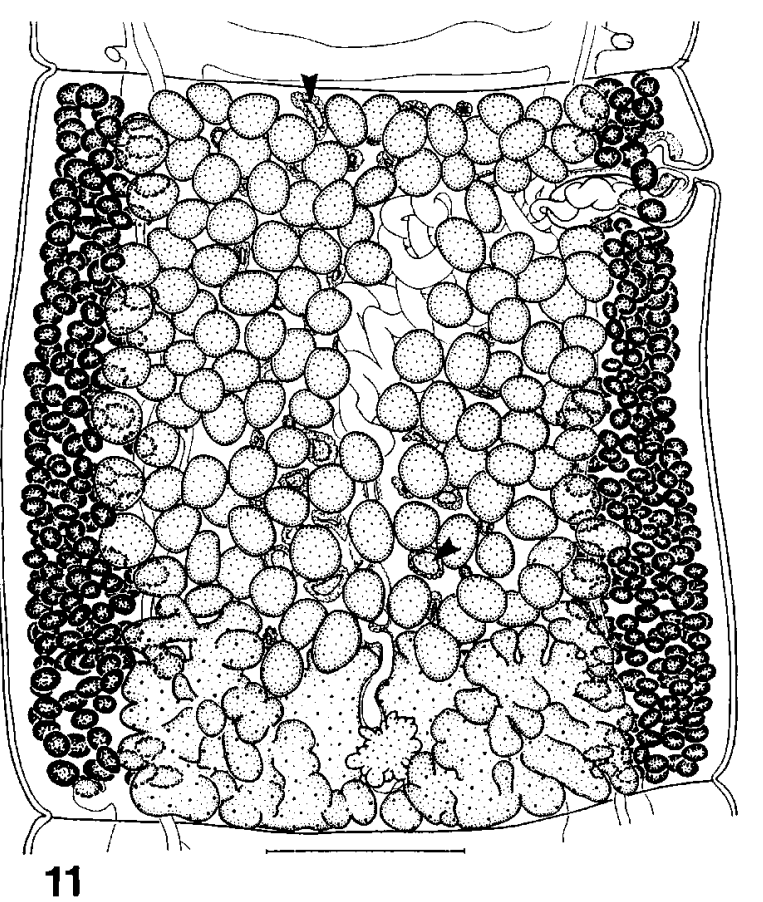

Figures 9-11. Position of testicular fields: 9. two distinctly separated fields, Proteocephalus soniae de Chambrier \& Vaucher, 1994 (after de Chambrier \& Vaucher, 1994); 10. two fields connected anteriorly, P. regoi de Chambrier \& al., 1996 (after Chambrier \& al., 1996); 11. one field, Mariauxiella pimelodi de Chambrier \& Rego, 1995 (after de Chambrier \& Rego, 1995). Scale-bars: 9, 10, $500 \mu \mathrm{m} ; 11,250 \mu \mathrm{m}$.

(21) Rostellum-like apical part of scolex armed with hooks. Two states: $0=$ absent; 1 = present. State 1 is present in the Gangesiinae.

(22) Lappet structures on apical part of scolex. Two states: $0=$ absent; $1=$ present. State 1 is present only in Sandonella sandoni (Lynsdale, 1960) (Sandonellinae).
(23) Arrangement of longitudinal musculature. Two states: 0 = isolated fibres; 1 = fibres concentrated together, forming distinct bundles.

(24) Spination on cirrus. Two states: $0=$ present; $1=$ absent. State 0 is present in Zygobothrium megacephalum Diesing, 1850 and in Nomimoscolex pirarara (Woodland, 1935) (both Zygobothriinae) and in Acanthotaeniinae and Gangesiinae. 

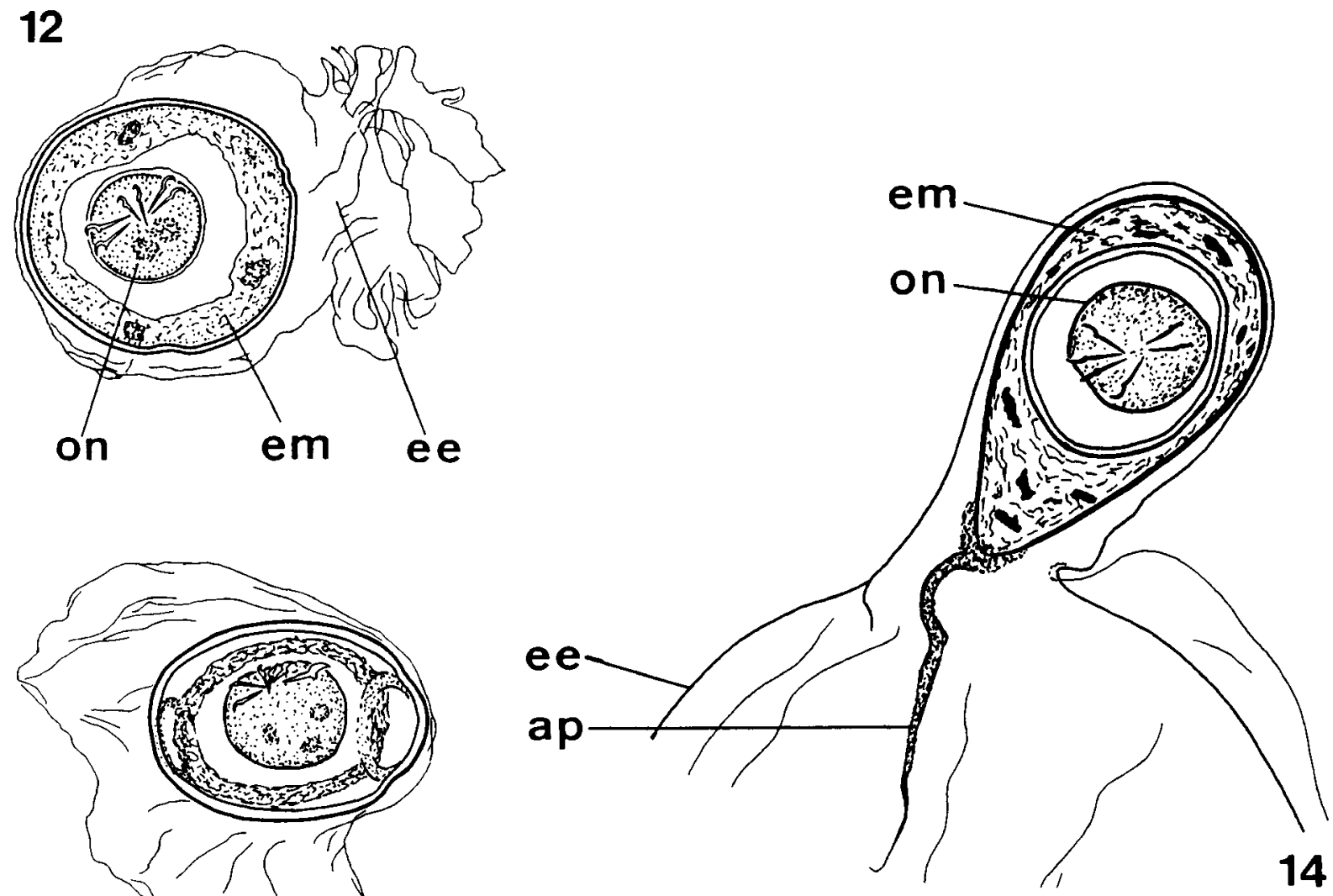

13

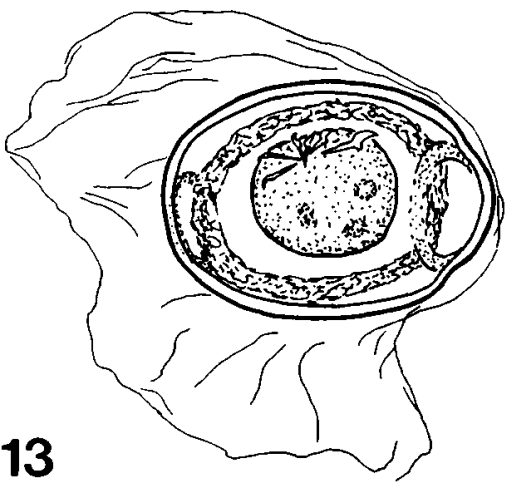

Figures 12-14. Egg structure: 12. egg spherical to oval, external hyaline membrane present, Nomimoscolex piraeeba Woodland, 1934 (after de Chambrier \& Vaucher, 1997); 13. internal polar circle-like structure present, Crepidobothrium eirasi Rego \& de Chambrier, 1995 (after Rego \& de Chambrier, 1995); 14. polar filaments present, Proteocephalus renaudi de Chambrier \& Vaucher, 1994 (de Chambrier \& Vaucher, 1994 ). Abbreviations: ap, appendix; ee, outer envelope; em, embryophore; on, oncosphere.

(25) "Spination" on suckers (presence of giant, spine-like microtriches on suckers). Two states: $0=$ absent; 1 = present. State 1 is present in some Proteocephalus spp. from snakes (Proteocephalinae), in Nomimoscolex piraeeba Woodland, 1934 (Zygobothriinae), in two species of Spasskyellina Freze, 1965 (Monticelliinae), and in the Acanthotaeniinae and Gangesiinae (de Chambrier \& Vaucher, 1997). "Spination" is considered here to be the presence of giant, spine-like microtriches forming a few rows on the margins and face of the suckers; microtriches are not considered homologous with true spines. Additionally, spination on the anterior region of the strobila as reported for the Acanthotaeniinae and Gangesiinae has been misinterpreted. The latter are identical to the microtriches present on the suckers, and similar to the very dense, filiform microtriches, previously observed (Thompson et al., 1980).
(26) Presence of piercing organ. Two states: $0=$ absent; $1=$ present. State 1 is present only in the Acanthotaeniinae.

(27) Longitudinal tegumental wrinkles. Two states: 0 = absent; 1 = present; State 1 is observed in the Marsypocephalinae, Proteocephalinae and in all subfamilies of the Monticelliidae except Rudolphiellinae. Longitudinal wrinkles are independent to the transverse wrinkles defined by character 15 .

\section{Phylogeny of subfamilies of the Proteocephalidea}

A single most parsimonious phylogenetic tree for relationships among the 12 proteocephalidean subfamilies (70 steps; $\mathrm{CI}=0.571$, excluding uninformative characters $=0.468 ; \mathrm{HI}=0.471$ and $0.559 ; \mathrm{RC}=0.295$ ), resulted from analysis of 27 morphological characters (Figure 18). Monophyly for the Proteocephalidea is 

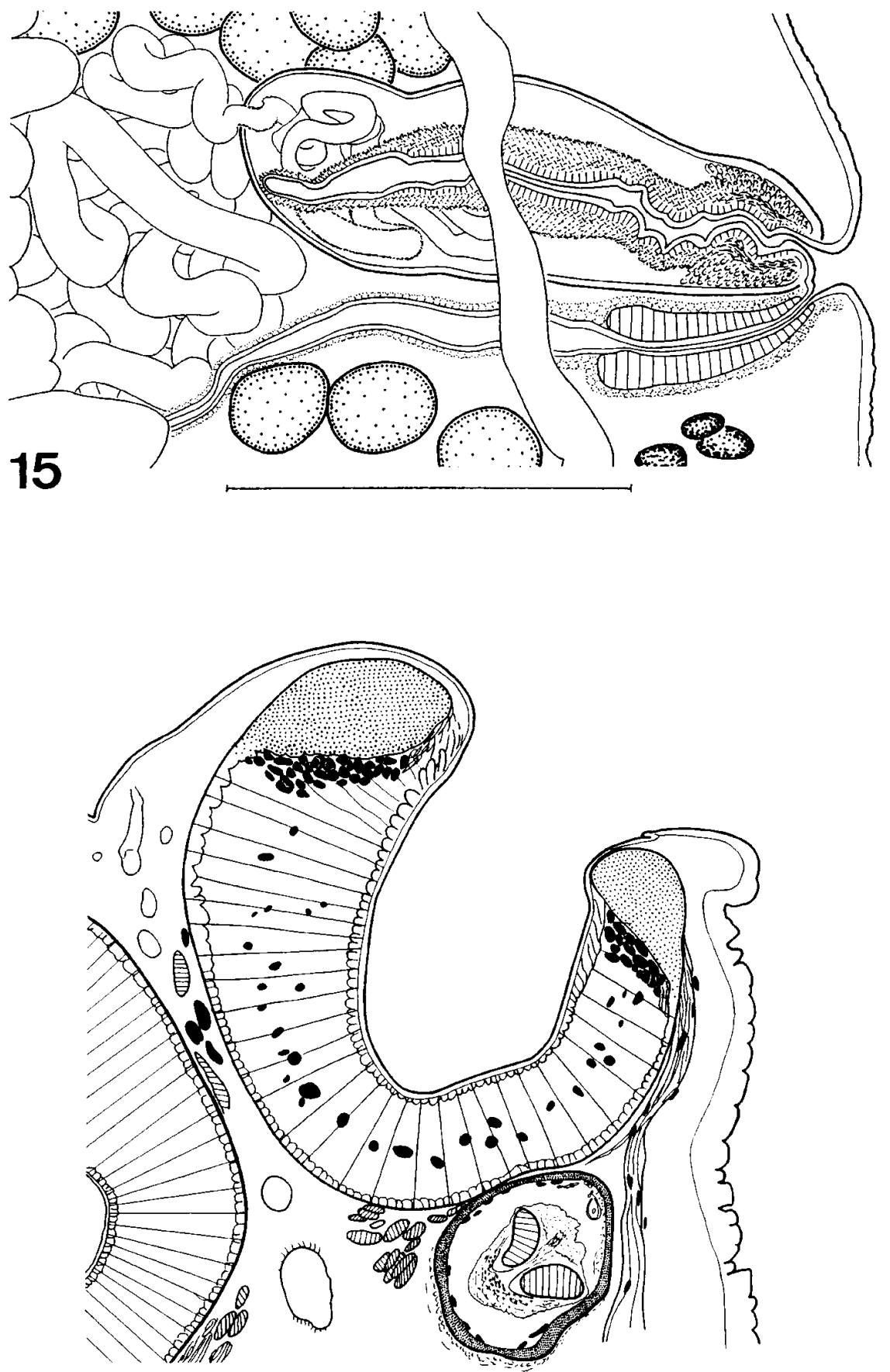

16

Figures 15-16. 15. Vaginal sphincter, Proteocephalus sophiae de Chambrier \& Rego, 1994 (after de Chambrier \& Rego, 1994). 16. Distal "sphincter" on suckers, Mariauxiella pimelodi de Chambrier \& Rego, 1995 (after de Chambrier \& Rego, 1995). Scale-bars: 15, $250 \mu \mathrm{m} ; 16$, $100 \mu \mathrm{m}$. 


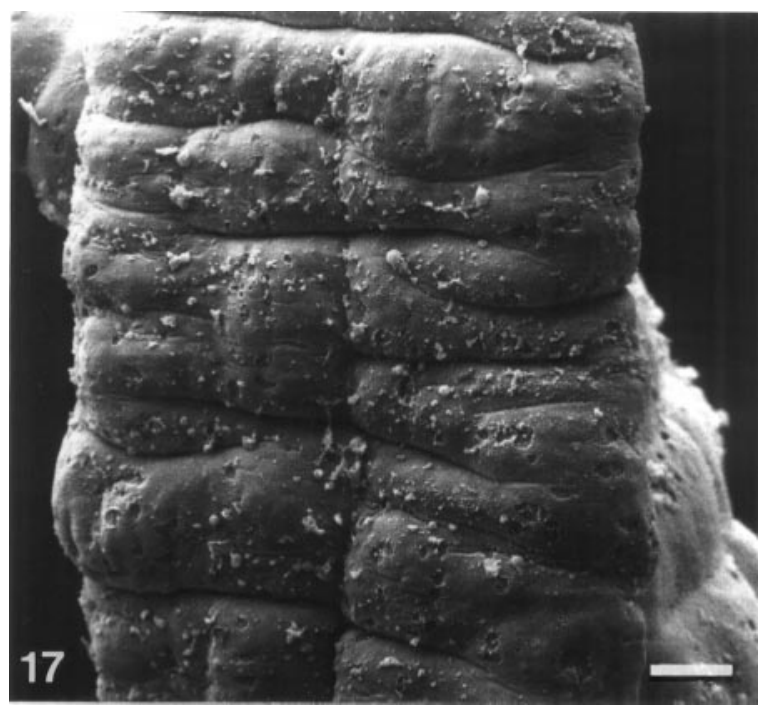

Figure 17. Transverse tegumental wrinkles, Endorchis piraeeba Woodland, 1934. Scale-bar: $100 \mu \mathrm{m}$.

diagnosed by the structure of the uterus (char. 7) and the presence of a vaginal sphincter (10). The latter character is ambiguous due to putative reversal in two subclades: (1) the Corallobothriinae + Proteocephalinae and Gangesiinae; and (2) the Zygobothriinae and Monticelliidae (Figure 18).

The Acanthotaeniinae are basal, followed by the Nupeliinae and two relatively diverse subclades: (1) the "Proteocephalidae" clade (Sandonellinae + Corallobothriinae + Proteocephalinae and Gangesiinae) and (2) the "Monticelliidae" clade (the Marsypocephalinae + Ephedrocephalinae and Othinoscolecinae + Rudolphiellinae + Monticelliinae and Zygobothriinae) (Figure 18). Support for the Proteocephalidae is based on the arrangement of the longitudinal musculature (char. 23), an attribute influenced by homoplasy. The Monticelliidae is diagnosed by the presence of transverse tegumental wrinkles (char. 15), an unambiguous attribute, and by the position of the testes (4) and longitudinal tegumental wrinkles (27). The latter character undergoes postulated reversal in the Rudolphiellinae.

It can be seen that neither Proteocephalidae nor Monticelliidae as currently conceived are monophyletic based on this analysis. For instance, the Nupeliinae are placed basally with respect to the remaining monticelliids. Additionally, two subfamilies regarded representatives of the Proteocephalidae, namely the Marsypocephalinae and Acanthotaeniinae, are not included within the family as defined by Rego (1994). The Acanthotaeniinae are placed as the basal subfamily of the Proteocephalidea and are separated from the other nominal taxa of the family by four synapomorphies (chars. 4, 11, 23 and 24) that diagnose relationships for higher taxa in the order. The Marsypocephalinae is grouped as the basal member of the Monticelliidae clade based on the presence of transverse tegumental wrinkles (char. 15). However, a tree one step longer results in the monophyly of both the Proteocephalidae and Monticelliidae, if the Acanthotaeniinae are excluded from the Proteocephalidae. Similarly, a tree two steps longer results in the monophyly for both families and includes all respective subfamilies consistent with current systematics as proposed by Rego (1994).

Regardless of these differences, some groupings are stable in the most parsimonious tree and those one or two steps longer. The Proteocephalinae + Gangesiinae are the sister group of the Corallobothriinae. The Sandonellinae are consistently placed as the basal taxon of the Proteocephalidae clade and are further diagnosed by a number of autapomorphies including the form of the vitellarium in two massive bodies posterior to ovary (char. 2), and structure of the scolex with lappets (char. 22). Additionally, subfamilies of the Monticelliidae clade, including the Monticelliinae + Zygobothriinae, are placed as the sister group of the Rudolphiellinae diagnosed by three homoplasious characters $(3,4$, and 11$)$; these subfamilies are the sister group of the Ephedrocephalinae + Othinoscolecinae diagnosed by two ambiguous attributes (14 and 23) (Figure 18). Homoplasy is widespread within the Proteocephalidea, particularly parallelism which was associated with 14 characters of the 27 characters examined in this analysis $(1,3-6,10,13,14,16,18,20$, 23, 25, and 27) (Table II).

\section{Biogeography}

The contemporary biogeographic distributions for subfamily level taxa are given in Table III and are mapped and optimised onto the parasite cladogram (Figure 19). Results of zoogeographical analysis appear to be compatible with a basal Gondwanan relationship (Figure 19, Table III). Extensive diversification occured in Africa and South America, with the origin of the group probably in the former region. Subsequent distribution of some groups (proteocephalid subfamilies Proteocephalinae, Corallobothriinae and Gangesiinae) extended into the Northern hemisphere (Holarctic Region). 


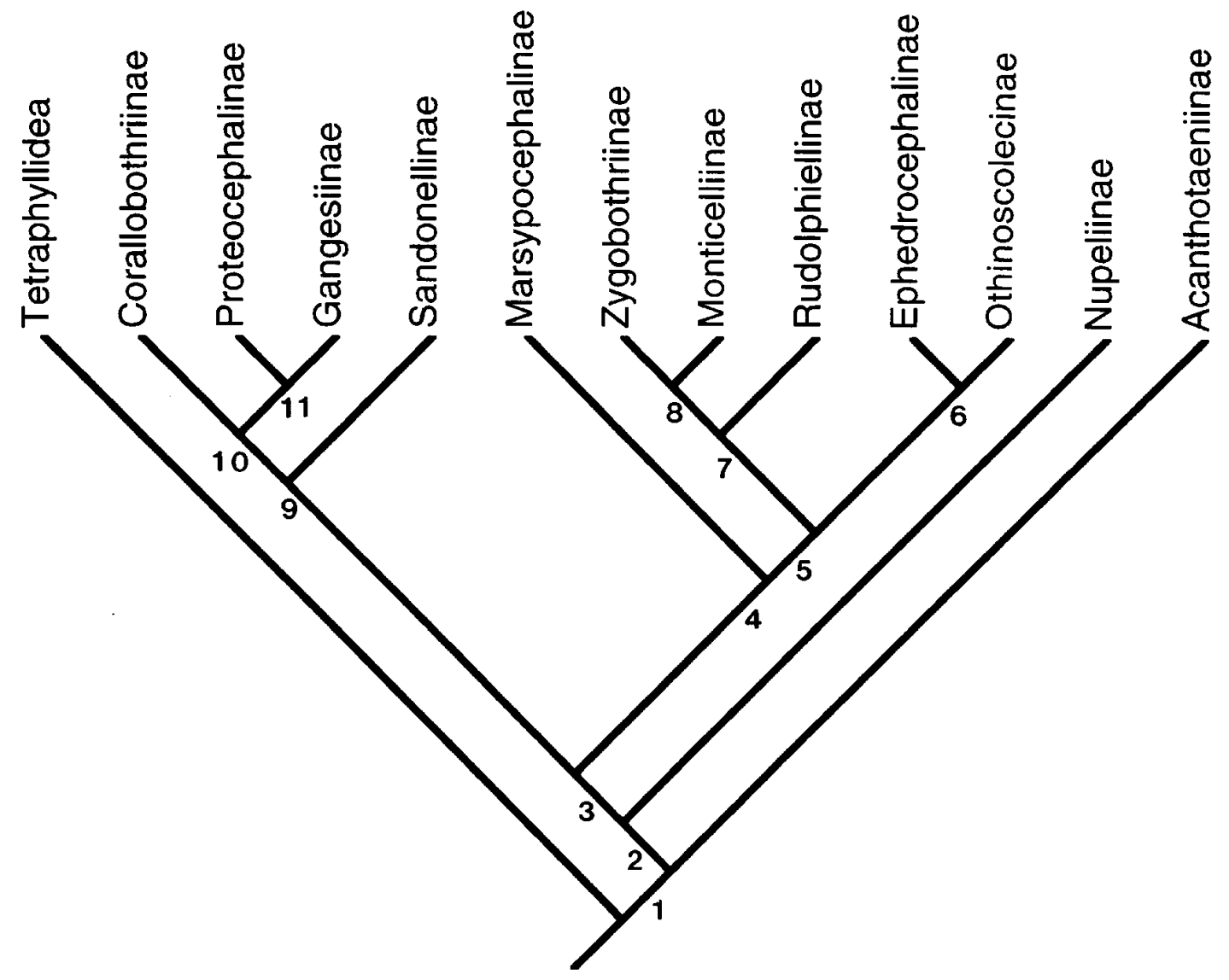

Figure 18. Phylogenetic hypothesis for the 12 nominal subfamilies of the Proteocephalidea based on comparative morphology. Shown is the single most parsimonious tree (minimum 40 steps, 70 required; $\mathrm{CI}=0.571 ; \mathrm{HI}=0.471$ ). Character support for each taxon and internode (numbered) is defined below and includes apomorphy (A), homoplasy as parallelism and convergence $(\mathrm{H})$, reversal (R), and polymorphism or change within terminal taxa (P). Terminal taxa are labelled accordingly: Acanthotaeniinae (A: 7, 26; H: 5, 11, 25; P: 14); Nupeliinae (A: 6, 4; H: 1, 3); Marsypocephalinae (H; 20); Rudolphiellinae (R: 27); Monticelliinae (A: 3, 8; H: 4; R: 11); Zygobothriinae (A: 6, 12, 17, 19; H: 5, 13, 20, 23, 25; R: 24); Othinoscolecinae (H: 16, 1, 20); Ephedrocephalinae (A: 2); Sandonellinae (A: 2, 22; H: 13, 14; P: 14); Corallobothriinae (H: 5, 16, 20); Gangesiinae (A: 21; R: 23); and Proteocephalinae (A: 1, 5, 11; H: 18, 27; P: 8). Internodes starting basally are designated as 1-11: 1: (A: 7, 10); 2: (A: 24); 3: (A: 11, 14); 4: (A: 15; H: 4, 27); 5: (H: 1, 16; R: 11); 6: (H: 14, 23); 7: H: 3, 11; R: 4); 8: (A: 9; H: 6, 18; R: 10); 9: (H: 23); 10: (R: 10); 11: (H: 25).

\section{Host relationships}

Analysis of parasite-host relationships indicates (Figure 20) that siluriform teleosts were the basal host group for the Nupeliinae + the proteocephalid and monticelliid subclades; basal hosts for the Proteocephalidea are unresolved. Non-siluriform teleosts were secondarily colonised by some proteocephalines and sandonellines. It can also be assumed that two independent colonisation events of Reptilia by the Proteocephalinae and Acanthotaeniinae took place, together with one colonisation of amphibians by some other proteocephaline cestodes (Table III, Figure 20).

\section{Discussion}

Monophyly for the Proteocephalidea is not disputed (see also Hoberg et al., 1997), but results indicate that concepts for the currently recognised families are not supported. Neither the Proteocephalidae nor the Monticelliidae constitute natural groups, based on the present analysis (see Figure 18; Table III). Two major and distinct subclades are consistently recognised: a Proteocephalidae group, including the Sandonellinae, Proteocephalinae, Corallobothriinae and Gangesiinae, and a Monticelliidae group, consisting of all monticelliid subfamilies, except for the Nupeliinae, 


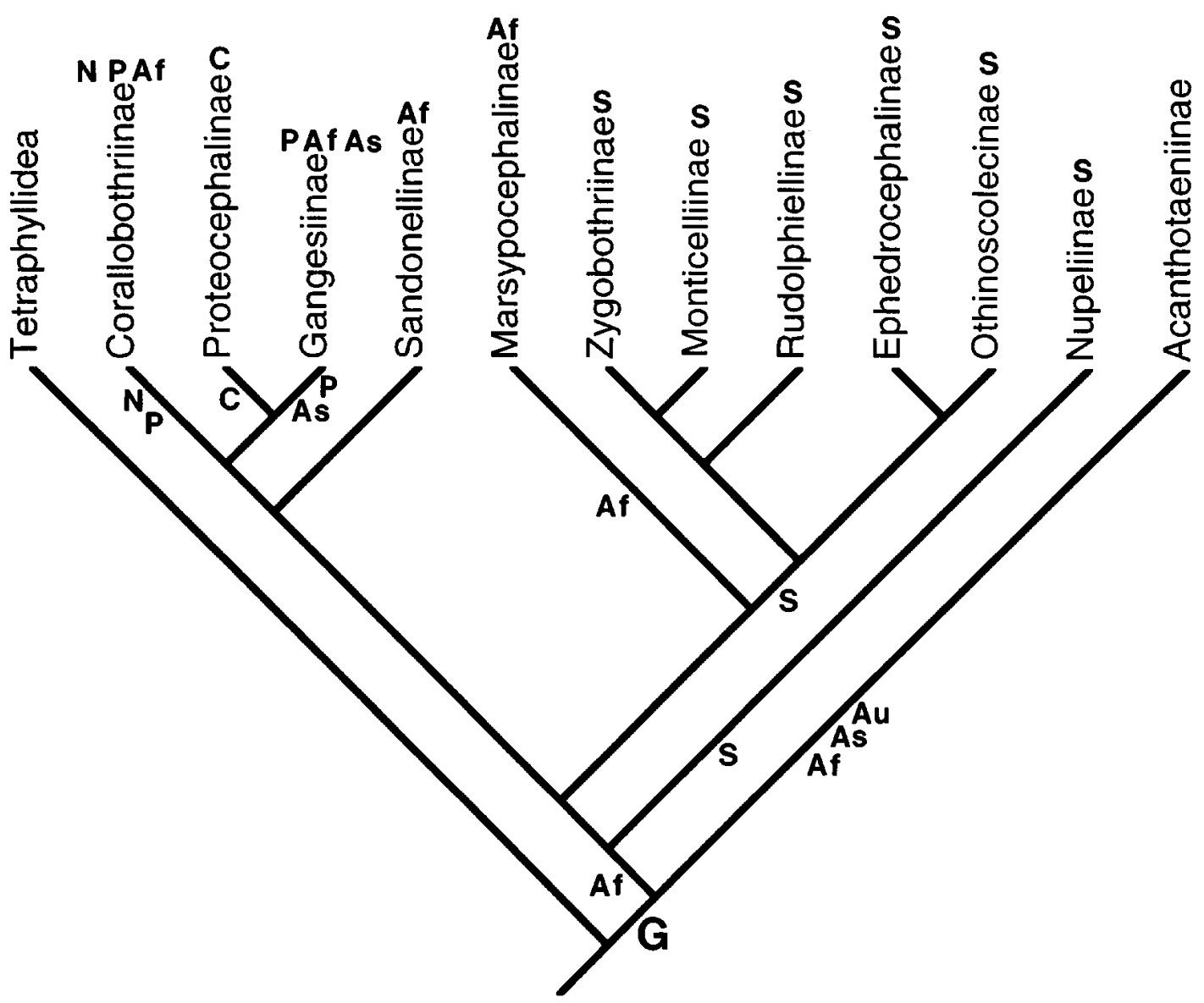

Figure 19. Phylogenetic hypothesis for the subfamilies of the Proteocephalidea with geographical distributions optimised onto the parasite cladogram. Labelling is consistent with Figure 18 and Table III. Geographical localities are indicated as follows: Af, Africa; As, Asia; Au, Australia; C, Cosmopolitan (some groups particularly the Proteocephalinae may have distributions which have been influenced secondarily by translocation and introduction of hosts and parasites across the Holarctic); G, Gondwanan; N, Nearctic; P, Palearctic; and S, South American. Terminal taxa are labelled and geographical distributions are optimised on the tree.

a subfamily established quite recently (Pavanelli \& Rego, 1991). Brooks et al. (1991) also suggested the polyphyletic origin of the Monticelliidae. In general, however, the topology of the tree and the relationships specified, are largely congruent with the systematic structure and classification of the proteocephalideans at the higher-level as presented by Rego (1994). It appears that the division of the order into two families is justified with each reflecting phylogenetic relationships among individual subfamilies. No support for recent proposal to suppress the Monticelliidae as a subfamily of the Proteocephalidae (Rego, 1995) has been obtained.

Considering relationships within the monticelliids, consistent with Brooks (1978b), a close relationship between Ephedrocephalinae and Othinoscolecinae was found. On the contrary, the present analysis did not support Brooks' (1978b) synonymy of the Rudolphiellinae as a member of the Monticelliinae. These subfamilies were placed in distinct subclades within the putative family, with the latter as the sister group of the Zygobothriinae (Figure 18).

The most significant departure from the current classification is in the placement of the Marsypocephalinae as the basal taxon of the monticelliid clade, and the basal placement of the Nupeliinae and the Acanthotaeniinae. As indicated, however, potential alternative trees, either one or two steps longer, would be entirely congruent with the currently proposed systematics for the order and relationships among the subfamilies. Consequently, it is premature to propose changes to the current taxonomy for the group. 


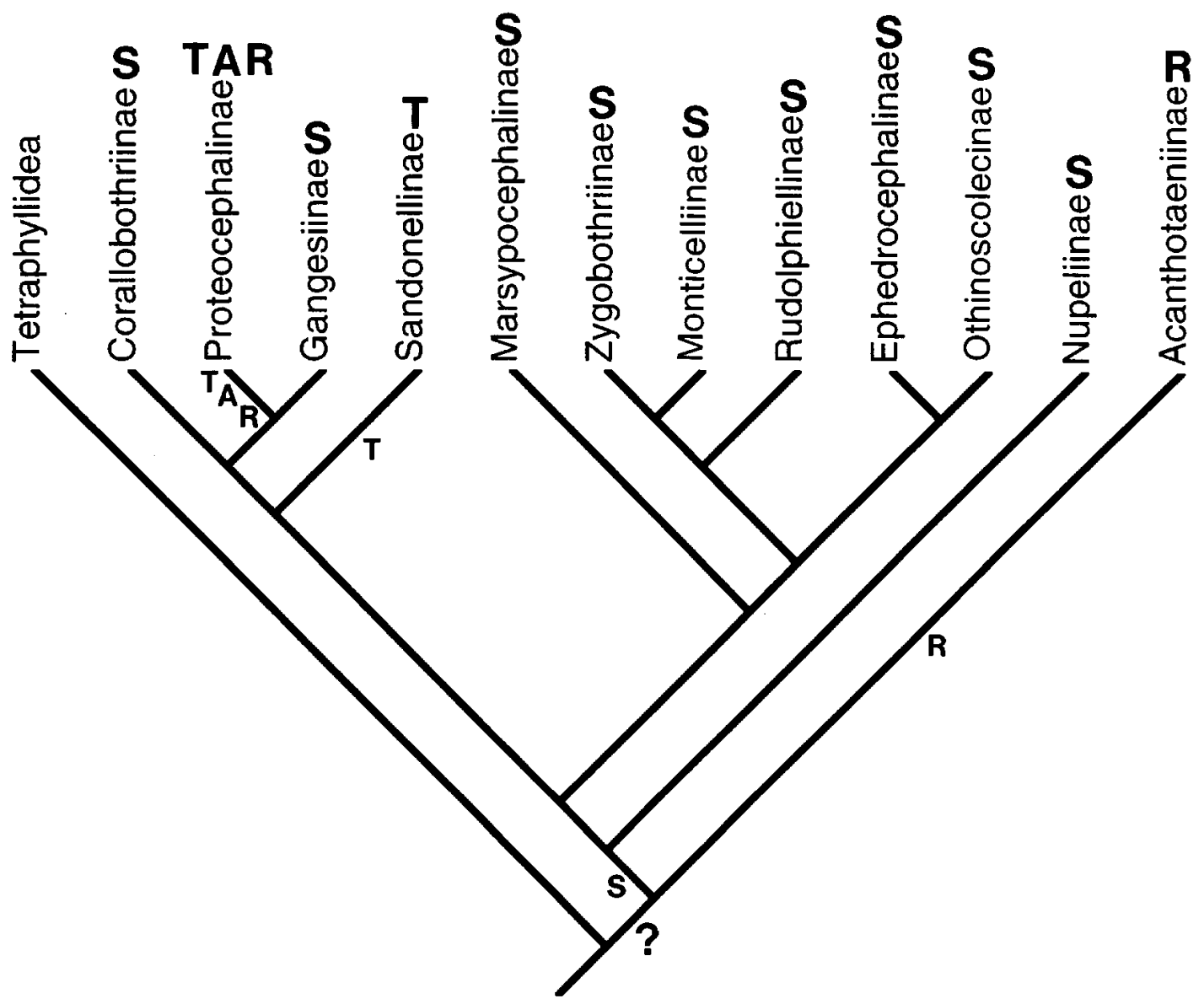

Figure 20. Phylogenetic hypothesis for the subfamilies of the Proteocephalidea with host occurrence optimised onto the parasite cladogram. Labelling is consistent with Figure 1 and Table III. Hosts are designated as follows: A, Amphibia; T, non-siluriform teleosts; R, Reptilia; S, siluriform fishes; ?, unresolved association. Terminal taxa are labelled and host associations are optimised on the tree.

Since the present study did not evaluate relationships at the generic level, it was not possible to evaluate groupings of many genera, particularly those within the Monticelliidae that were considered artificial by Brooks \& Rasmussen (1984, figure 11). Results presented by these authors may reflect existing confusion in generic diagnoses of many taxa rather than a clear indication of the necessity to modify classifications of the group. Similarly, a new arrangement of the Monticelliidae, including numerous synonymies of genera proposed by Brooks (1995), requires critical evaluation coinciding with the broadening of our knowledge from comparative morphology. As an example, the recent revision of the monticelliid genus Nomimoscolex, which resulted in numerous synonymies and new combinations (de Chambrier \& Vaucher, 1997), can be mentioned.
Brooks (1995) suggested that the current level of resolution in phylogenetic studies of the monticelliids (and this can be extended to the proteocephalideans in general) was limited by the availability of character information for many taxa. Homoplasy was considered to be relatively minimal in the characters evaluated (e.g. $\mathrm{CI}=0.73$ ). In contrast, the current analysis resulted in recognition of substantial levels of homoplasy, primarily definable as parallel development (e.g. $\mathrm{CI}=0.571$; with 14 of 27 characters exhibiting some level of homoplasy) (Table II). Thus, it is apparent that much more data must be evaluated in order to critically assess relationships within the order Proteocephalidea.

Historical biogeography for the proteocephalideans is complex and clearly associated with Gondwana (Figure 19). The current analysis is compatible with basal Gondwanan relationships, initial diversification in Africa, and with radiation in some taxa occurring 
Table II. Consistency indices for individual characters used in analysis of the Proteocephalidea as an indication of the degree of homoplasy

\begin{tabular}{|c|c|c|}
\hline Character number & Character & CI \\
\hline 1 & vitelline position & 0.667 \\
\hline 2 & vitelline topography & 1.000 \\
\hline 3 & ovary position & 0.667 \\
\hline 4 & testes position & 0.500 \\
\hline 5 & testicular field & 0.500 \\
\hline 6 & uterus position & 0.500 \\
\hline 7 & uterus shape & 1.000 \\
\hline 8 & egg structure & 0.500 \\
\hline 9 & egg embryonation & 1.000 \\
\hline 10 & vaginal sphincter & 0.333 \\
\hline 11 & vagina position & 0.333 \\
\hline 12 & genital pore & 1.000 \\
\hline 13 & proglottis type & 0.500 \\
\hline 14 & proglottis shape & 0.800 \\
\hline 15 & teg. wrinkles, transverse & 1.000 \\
\hline 16 & metascolex & 0.333 \\
\hline 17 & apical organ & 1.000 \\
\hline 18 & sucker structure & 0.250 \\
\hline 19 & auricula & 1.000 \\
\hline 20 & "sphincter" on suckers & 0.250 \\
\hline 21 & rostellum & 1.000 \\
\hline 22 & lappet structures & 1.000 \\
\hline 23 & longitudinal muscles & 0.250 \\
\hline 24 & "spination" of cirrus & 0.500 \\
\hline 25 & "spination" of suckers & 0.333 \\
\hline 26 & piercing organ & 1.000 \\
\hline 27 & teg. wrinkles, longitudinal & 0.333 \\
\hline
\end{tabular}

prior to the breakup of the supercontinent. Fragmentation of Gondwana is reflected in the geographical distributions of the Marsypocephalinae + remaining monticelliids (Figure 19). Secondary expansion into the Northern Hemisphere is evident among the Corallobothriinae, Proteocephalinae and the Gangesiinae.

Brooks (1978b), however, considered Gondwanian South America to be the centre of origin for the Proteocephalidea. Irrespective of this difference, the present analysis suggests subsequent distributional history of proteocephalideans linking Africa and South America, with an extensive radiation in the latter continent after its separation from Africa. It can also be presumed that proteocephalid subfamilies (Proteocephalinae, Corallobothriinae and Gangesiinae) subsequently dispersed with their hosts into the Northern Hemisphere, with members of the former
Table III. Geographical distribution and host spectrum for the subfamilies of the Proteocephalidea

\begin{tabular}{llll}
\hline Subfamily & Family $^{1}$ & Hosts $^{2}$ & Geographical distribution \\
\hline Corallobothriinae & P & Pi-S & Nearctic, Palearctic \& Africa \\
Gangesiinae & P & Pi-S & Africa, Asia, Palearctic \\
Proteocephalinae & P & Pi,A,R & cosmopolitan \\
Sandonellinae & P & Pi & Africa \\
Marsypocephalinae & P & Pi-S & Africa \\
Zygobothriinae & M & Pi-S & S. America \\
Monticelliinae & M & Pi-S & S. America \\
Rudolphiellinae & M & Pi-S & S. America \\
Ephedrocephalinae & M & Pi-S & S. America \\
Othinoscolecinae & M & Pi-S & S. America \\
Nupeliinae & M & Pi-S & S. America \\
Acanthotaeniinae & P & R & Africa, Asia, Australia \\
\hline
\end{tabular}

${ }^{1} \mathrm{P}$, Proteocephalidae; M, Monticelliidae.

$2 \mathrm{Pi}$, Pisces [teleosts] (mostly siluriform - S); A, Amphibia; R, Reptilia.

3 Postgangesia parasiluri, previously placed in the Zygobothriinae (see Schmidt, 1986; Rego, 1994), is in fact Gangesia parasiluri, a member of the Gangesiinae, as stated previously by Dubinina (1971, 1987).

${ }^{4}$ One species, Acanthotaenia overstreeti Brooks \& Schmidt, 1978, was described from Cyclura stejnegeri in Puerto Rico.

subfamily group becoming cosmopolitan in distribution.

Examination of host-parasite associations suggests that teleosts were basal hosts for the proteocephalideans, although the basal node linking the Acanthotaeniinae and other subfamily level taxa must be regarded as equivocal. Excluding the Acanthotaeniinae, which occur in reptilian hosts, optimisation of host occurrence on the phylogenetic tree would suggest siluriform fishes as basal hosts for the remaining proteocephalideans (Figure 20); an extensive history of co-evolution with catfishes of the Neotropics is postulated. In contrast, the host associations of proteocephaline and acanthotaeniine cestodes in the present phylogenetic tree may be consistent with two independent colonisation events of reptilians. Additionally associations of proteocephalines with amphibians and other teleosts, and sandonellines with teleosts, represent putative event of host-switching (Figure 20). This strongly corroborates the original hypothesis for host relationships among the proteocephalideans, as proposed by Brooks (1978b; see figure 8 of Brooks) 


\section{Summary and conclusions}

Despite some differences between results of the present phylogenetic analysis and current classification of the Proteocephalidea, no changes in the taxonomy of this cestode group are proposed. This analysis, although the first one based on critical study of existing data, is considered to be preliminary due to the limited information about some taxa. Similarly, the taxonomic position of some subfamilies (Acanthotaeniinae, Nupeliinae, Marsypocephalinae and Sandonellinae) remains problematical. Although the current analysis supports recognition of the proteocephalideans as monophyletic, this hypothesis requires continued evaluation (see Brooks et al., 1991)

Regarding the future, any phylogenetic analysis at generic or lower levels within the Proteocephalidea should be preceded by a revision of the characters based on type, voucher and recently collected material. Particularly, consideration of the following points for the future progress in the taxonomy of the group and its phylogenetic relationships is strongly encouraged by the present authors:

(1) More detailed and complete redescriptions of inadequately characterised taxa are recommended. For example, members of some subfamilies like the Sandonellinae, Nupeliinae, Gangesiinae, Acanthotaeniinae, and Marsypocephalinae are poorly known.

(2) We suggest that further taxonomic work should be based only on adequately processed material. For example, good results were obtained with fixation of living worms with hot $4 \%$ formaldehyde and staining with Mayer's iron paracarmine. It is recommended to avoid excessive relaxation of worms in water, which often results in vacuolisation of tissues and damage of the tegument. The fixation process should attempt to eliminate excessive levels of contraction of the strobila; artificial flattening of the worms is to be discouraged. Technical information for fixation and preparation of specimens has been published and discussed in several papers, including Anonymous (1957), Pritchard \& Kruse (1982), Gibson (1984), Georgiev et al. (1986) and de Chambrier (1987).

(3) In order to precisely observe the internal topography of genital organs and longitudinal musculature, morphological study must include transverse sections.

(4) The search for new characters should continue (see Mariaux, 1996; Hoberg et al., 1997). Of particular promise may be attributes derived from histology, ultrastructural analysis (SEM and TEM) and comparative evaluations of the surface morphology of the scolex allowing observations of complex structures such as the apical organ, glandular cells and other attributes. It is vital to have synoptic descriptions of uterine ontogeny and structure, along with details of oncospheres and egg envelopes. Helpful observations of egg structure can be obtained with eggs released from the terminal proglottides and observed in water.

(5) Substantial progress also could be achieved with respect to studies of the life-cycles of most proteocephalidean groups. For example, it is vital that this information be obtained for species parasitising South American fishes and reptiles, including all members of the Monticelliidae. Studies published previously, limited primarily to members of the Proteocephalinae, have indicated that copepods are exclusive first intermediate hosts of proteocephalideans (Freze, 1965; Scholz, 1991, 1993). Variation in egg structure among some South American species however, suggests that several life-cycle patterns exist among Proteocephalidea.

The current analysis summarises the current body of data available from comparative morphology. Generalities are apparent with respect to conclusions of this analysis and previous concepts for the systematics of the Proteocephalidea. This can now promote a hierarchical and top down approach to the evaluation of genera and species (e.g. Hoberg et al., 1997) in the pursuit of a refined understanding of the systematics, host-associations and historical biogeography of these fascinating tapeworms.

\section{Acknowledgements}

This is a contribution from the 2nd International Worskhop for Tapeworm Systematics (E.P. Hoberg, S.L. Gardner and R.A. Campbell, organisers), held at the University of Nebraska-Lincoln on 2-6 October 1996. The authors express their deep gratitude to organisers of the Workshop for providing excellent working conditions and friendly atmosphere enabling preparation of data base for this paper. The authors are grateful to Dr Claude Vaucher, Geneva, for fruitful suggestions. Prof. Louis Euzet, Sete, France, is acknowledged for providing valuable advice and important information about the Tetraphyllidea. The participation of Tomás Scholz was supported financially by grant no. 508-95-0294 of the Grant Agency of the Czech Republic. 


\section{References}

Anonymous (1957) How to collect parasites. Methods adopted by the First Symposium on Host Specificity among Parasites of Vertebrates. In: Attinger, P. (Ed.) First Symposium on Host Specificity among Parasites of Vertebrates. Neuchâtel, 324 pp.

Brooks, D.R. (1978a) Systematic status of the proteocephalid cestodes of North American reptiles and amphibians. Proceedings of the Helminthological Society of Washington, 45, 1-28.

Brooks, D.R. (1978b) Evolutionary history of the cestode order Proteocephalidea. Systematic Zoology, 27, 312-323.

Brooks, D.R. (1995) Phylogenetic hypothesis, cladistic diagnoses, and classification of the Monticelliidae (Eucestoda: proteocephaliformes). Revista Brasileira de Biologia, 55, 359-367.

Brooks, D.R., Hoberg, E.P. \& Weekes, P.J. (1991) Preliminary phylogenetic systematic analysis of the major lineages of the Eucestoda (Platyhelminthes: Cercomeria). Proceedings of the Biological Society of Washington, 104, 651-668.

Brooks, D.R. \& McLennan, D. A. (1993) Parascript. Parasites and the language of Evolution. Washington \& London: Smithsonian Institution Press, 429 pp.

Brooks, D.R. \& Rasmussen, G. (1984) Proteocephalid cestodes from Venezuelan catfish, with a new classification of the Monticelliidae. Proceedings of the Biological Society of Washington, 97, 748-760.

de Chambrier, A. (1987) Vaucheriella bicheti n. gen., n. sp. (Cestoda: Monticelliidae, Zygobothriinae) parasite de Tropidophis cf. taczanowskyi (Steindachner, 1880) (Serpentes: Tropidophidae) des Andes équatoriennes. Revue Suisse de Zoologie, 94, 829-840.

de Chambrier, A. (1988) Crepidobothrium garzonii n. sp. (Cestoda: Proteocephalidae) parasite de Bothrops alternatus Dum. Bibr. \& Dum., 1854 (Serpentes: Viperidae) au Paraguay. Revue Suisse de Zoologie, 95, 1,163-1,170.

de Chambrier, A. (1989a) Révision du genre Crepidobothrium Monticelli, 1900 (Cestoda: Proteocephalidae) parasite d'Ophidiens néotropicaux. I. C. gerrardii (Baird, 1860) et C. viperis (Beddard, 1913). Revue Suisse de Zoologie, 96, 191-217.

de Chambrier, A. (1989b) Révision du genre Crepidobothrium Monticelli, 1900 (Cestoda: Proteocephalidae) parasite d'Ophidiens néotropicaux. II. C. dollfusi Freze, 1965, C. lachesidis (MacCallum, 1921) et conclusions. Revue Suisse de Zoologie, 96, 345-380.

de Chambrier, A. (1990) Redescription de Proteocephalus paraguayensis (Rudin, 1917) (Cestoda: Proteocephalidae) parasite de Hydrodynastes gigas (Dum., Bibr. \& Dum., 1854) du Paraguay. Systematic Parasitology, 16, 85-97.

de Chambrier, A. \& Rego, A.A. (1994) Proteocephalus sophiae n. sp. (Cestoda: Proteocephalidae) a parasite of the siluroid fish Paulicea luetkeni (Pisces: Pimelodidae) from the Brazilian Amazon. Revue Suisse de Zoologie, 101, 361-368.

de Chambrier, A. \& Rego, A.A. (1995) Mariauxiella pimelodi n. g., n. sp. (Cestoda: Monticelliidae): a parasite of pimelodid siluroid fishes from South America. Systematic Parasitology, 30, 57-65.

de Chambrier, A., Scholz, T. \& Vaucher, C. (1996) Tapeworms (Cestoda: Proteocephalidea) of Hoplias malabaricus (Pisces: Characiformes, Erythrinidae) in Paraguay: description of Proteocephalus regoi sp. n., and redescription of Nomimoscolex matogrossensis. Folia Parasitologica, 43, 133-140.

de Chambrier, A. \& Vaucher, C. (1984) Proteocephalus gaspari $\mathrm{n}$. sp. (Cestoda: Proteocephalidae), parasite de Lepisosteus tropicus (Gill) au Lac Managua (Nicaragua). Revue Suisse de Zoologie, 91, 229-233. de Chambrier, A., Vaucher, C. \& Renaud, F. (1992) Etude des caracteres morpho-anatomiques et des flux géniques chez quatre Proteocephalus (Cestoda: Proteocephalidae) parasites de Bothrops jararaca au Brésil et description de trois especes nouvelles. Systematic Parasitology, 23, 141-156.

de Chambrier, A. \& Vaucher, C. (1992) Nomimoscolex touzeti $\mathrm{n}$. sp. (Cestoda), a parasite of Ceratophrys cornuta (L.): first record of a Monticelliidae in an amphibian host. Memorias do Instituto Oswaldo Cruz, 87, 61-67.

de Chambrier, A. \& Vaucher, C. (1994) Etude morpho-anatomique et génétique de deux nouveaux Proteocephalus Weinland, 1858 (Cestoda: Proteocephalidae) parasites de Platydoras costatus (L.), poisson siluriforme du Paraguay. Systematic Parasitology, 27, 173-185.

de Chambrier, A. \& Vaucher, C. (1997) Révision des cestodes (Monticelliidae) décrits par Woodland (1934) chez Brachyplatystoma filamentosum avec redéfinition des genres Endorchis Woodland, 1934 et Nomimoscolex Woodland, 1934. Systematic Parasitology, 37, 219-233.

de Chambrier, A. \& Paulino, R. C. (1997) Proteocephalus joanae sp. n., a parasite of Xenodon neuwiedi (Serpentes: Colubridae) from South America. Folia Parasitologica, 44, 289-296.

Dubinina, M.N. (1971) Tapeworms of fish of the Amur River basin. Parazitogicheskii sbornik of the Zoological Institute of the Academy of Sciences of the USSR, 25, 77-119. (In Russian).

Dubinina, M.N. (1987) Class Cestoda Rudolphi, 1808. In: Bauer, O.N. (Ed.) Key to the parasites of freshwater fishes. Vol. 3., Leningrad: Nauka, pp. 5-76. (In Russian).

Euzet, L. (1994) Order Tetraphyllidea Carus, 1863. In: Khalil, L.F, Jones, A. \& Bray, R.A. (Eds) Keys to the cestode parasites of vertebrates, Wallingford: CAB International, pp. 149-194.

Freze, V.I. (1965) Essentials of cestodology. Vol. V. Proteocephalata in fish, amphibians and reptiles. Moskva: Izdatel'stvo "Nauka", 538 pp. (In Russian: English translation, Israel Program of Scientific Translation, 1969, Cat. No. 1853. v + 597 pp).

Fuhrmann, O. (1931) Dritte Klasse des Cladus Plathelminthes Cestoidea. In: Kukenthal, W. \& Krumbach, T. (Eds) Handbuch der Zoologie, Berlin und Leipzig: Bogen, 1930-1931, Vol. 2, $141-416$.

Georgiev, B., Biserkov, V. \& Genov, T. (1986) In toto staining method for cestodes with iron acetocarmine. Helminthologia, 23, 279-281.

Gibson, D.I. (1984) Technology as applied to museum collections: the collection, fixation and conservation of Helminths. Systematic Parasitology, 6, 241-255.

Hanzelová, V. \& Scholz, T. (1992) Redescription of Proteocephalus neglectus La Rue, 1911 (Cestoda: Proteocephalidae), a trout parasite, including designation of its lectotype. Folia Parasitologica, 39, 317-323.

Hanzelová, V. \& Scholz, T. (1993) Systematic status of Proteocephalus tumidocollis (Cestoda: Proteocephalidae), a parasite of salmonid fishes in North America. Helminthologia, 30, 157-161.

Hanzelová, V. \& Spakulová, M. (1992) Biometric variability of Proteocephalus neglectus (Cestoda: Proteocephalidae) in two different age groups in the rainbow trout from the Dobsiná dam (East Slovakia). Folia Parasitologica, 39, 307-316.

Hanzelová, V., Scholz, T. \& Fagerholm, H.-P. (1995a) Synonymy of Proteocephalus neglectus La Rue, 1911, with P. exiguus La Rue, 1911, two fish cestodes from the Holarctic Region. Systematic Parasitology, 30, 173-185.

Hanzelová, V., Spakulová, M., Snábel, V., Kralová, I. \& Fagerholm, H.-P. (1995b) A comparative study of the fish parasites Proteocephalus exiguus and P. percae (Cestoda: Proteocephalidae): 
morphology, isoenzymes, and karyotype. Canadian Journal of Zoology, 73, 1191-1198.

Hennig, W. (1950) Grundzüge einer Theorie der phylogenetischen Systematik. Berlin: Deutscher Zentralverlag, 370 pp.

Hennig, W. (1966) Phylogenetic systematics. Urbana: University of Illinois Press, $263 \mathrm{pp}$

Hoberg, E.P. \& Lichtenfels, J.R. (1994) Phylogenetic systematic analysis of the Trichostrongylidae (Nematoda), with an initial assessment of coevolution and biogeography. Journal of Parasitology, 80, 976-996.

Hoberg,. E.P., Mariaux, J., Justine, J.-L., Brooks, D.R. \& Weekes, P. (1997) Phylogeny of the orders of the Eucestoda (Cercomermomorphae) based on comparative morphology: historical prespectives and a new working hypothesis. Journal of Parasitology, 83, In Press.

La Rue, R.B. (1911) A revision of the cestode family Proteocephalidae. Zoologischer Anzeiger, 38, 473-482.

La Rue, R.B. (1914) A revision of the cestode family Proteocephalidae. Illinois Biological Monographs, 1, 3-351.

Lynsdale, J.A. (1959) On a new species of Proteocephalus from Brazil. Journal of Helminthology, 34, 43-46.

Maddison, W.P. \& Maddison, D.R. (1993) MacClade: analysis of phylogeny and character evolution. Version 3.05. Sunderland, Massachusetts: Sinauer Associates.

Maddison, W.P., Donoghue, M.J., \& Maddison D.R. (1984) Outgroup analysis and parsimony. Systematic Zoology, 33, 83-103.

Mariaux, J. (1996) Cestode systematics: Any progress? International Journal for Parasitology, 26, 231-243.

Pavanelli, G. \& Rego, A.A. (1991) Cestoides proteocephalideos de Sorubim lima (Schneider, 1801) (Pisces: Pimelodidae) do Rio Parana e reservatorio de Itaipu. Revista Brasileira de Biologia, 51, 7-12.

Pritchard, M.H. \& Kruse, G.O.W. (1982) The collection and preservation of animal parasites. Lincoln and London: University of Nebraska Press, 141 pp.

Rego, A.A. (1987) Cestoides proteocefalideos do Brasil, reorganizaçao taxonomica. Revista Brasileira de Biologia, 47, 203-212.

Rego, A.A. (1991) Redescription of Nomimoscolex piraeeba Woodland, 1934 (Cestoda: Proteocephalidea), from the amazon catfishes, Brachyplatystoma spp. with proposal of synonyms and invalidation of Endorchiinae and Endorchis. Memorias do Instituto Oswaldo Cruz, 86, 229-232.

Rego, A.A. (1994) Order Proteocephalidea Mola, 1928. In: Khalil L.F, Jones A. \& Bray R.A. (Eds) Keys to the cestode parasites of vertebrates. Wallingford: CAB International, pp. 257-293.

Rego, A.A. (1995) A new classification of the cestode order Proteocephalidea Mola. Revista Brasileira de Zoologia, 12, 791-814.

Rego, A.A. \& de Chambrier, A. (1995) Crepidobotrium eirasi n. sp. (Cestoda: Proteocephalidae), a parasite of the siluroid fish Phractocephalus hemioliopterus (Schneider, 1801) (Pisces: Pimelodidae from the Brazilian Amazon. Revue Suisse de Zoologie, 102, 3-11.

Rego, A.A., Dos Santos, J.C. \& Silva, P.P. (1974) Estudos de cestoides de peixes do Brasil. Memorias do Instituto Oswaldo Cruz, 72, 187-204.

Rego, A.A., \& Pavanelli, G.C. (1985) Jauella glandicephalus gen. n., sp. n. e Megathylacus brooksi sp.n., cestoides patogenicos para o Jau, Paulicea luetkeni, peixe pimelodideos. Revista Brasileira de Biologia, 45, 643-652.

Rego, A.A. \& Pavanelli, G.C. (1990) Novas especies de cestoides proteocephalideos parasitas de peixes nao siluriformes. Revista Brasileira de Biologia, 50, 91-101.

Rego, A.A. \& Pavanelli, G.C. (1991) Proteocephalus gibsoni nom. nov. for Proteocephalus ocellatus Rego \& Pavanelli, 1990 pre- occupied by Proteocephalus ocellatus (Rudolphi, 1802). Revista Brasileira de Biologia, 51, 701.

Rego, A.A. \& Pavanelli, G.C. (1992) Checklist of the cestode order Proteocephalidea parasites from South America freshwater fishes. Revista Unimar, Maringa, 14 (Suppl.), 109-137.

Riggenbach, E. (1896) Das Genus Ichthyotaenia. Revue Suisse de Zoologie, 4, 165-275.

Schmidt, G.D. (1986) Handbook of tapeworm identification. Boca Raton, Florida: C.R.C. Press Inc., 675 pp.

Scholz, T. (1989) Amphilinida and Cestoda, parasites of fish in Czechoslovakia. Acta Scientiarum Naturalium Academiae Scientiarum Bohemoslovacae Brno, 23, No. 4, 56 pp.

Scholz, T. (1991) Studies on the development of the cestode Proteocephalus neglectus La Rue, 1911 (Cestoda: Proteocephalidea) under experimental conditions. Folia Parasitologica, 38, 309318.

Scholz, T. (1993) Development of Proteocephalus torulosus (Batsch, 1786) (Cestoda: Proteocephalidae) in the intermediate host under experimental conditions. Journal of Helminthology, 67, 316-324.

Scholz, T., de Chambrier, A., Prouza, A. \& Royero, R. (1996) Redescription of Proteocephalus macrophallus, a parasite of $\mathrm{Ci}$ chla ocellaris (Pisces: Cichlidae) from South America. Folia Parasitologica, 43, 287-291.

Scholz, T. \& Cappellaro, H. (1993) Corallobothrium parafimbriatum Befus et Freeman, 1973 (Cestoda, Proteocephalidae), a parasite of North American catfishes (Ictalurus spp.) newly introduced into Europe. Folia Parasitologica, 40, 105-108.

Scholz, T. \& Ergens, R. (1990) Cestodes of fishes from Mongolia. Acta Societatis Zoologicae Bohemoslovacae, 54, 287-304.

Scholz, T. \& Hanzelová, V. (1994) Taxonomic study of two Proteocephalus species (Cestoda: Proteocephalidae) parasitising coregonid fishes: the synonymy of $P$. fallax La Rue, 1911 with $P$. exiguus La Rue, 1911. Systematic Parasitology, 27, 1-12.

Scholz, T., Hanzelová, V. \& Snábel, V. (1995) The taxonomic status of Proteocephalus dubius La Rue, 1911 (Cestoda: Proteocephalidae), a puzzling parasite of perch (Perca fluviatilis L.). Parasite, 2, 231-234.

Scholz, T., Spakulová, M., Snábel, V., Kralová, I. \& Hanzelová, V. (1997) A multidisciplinary approach to the systematics of Proteocephalus macrocephalus (Cestoda: Proteocephalidae). Systematic Parasitology, 38, 1-12.

Swofford, D. (1993) Phylogenetic analysis using parsimony. Version 3.1.1. Computer program distributed by the Illinois Natural History Survey, Champaign, illinois.

Thompson, R.C.A., Hayton, A.R. \& Jue Sue, L.P. (1980) An ultrastructural study of the microtriches of adult Proteocephalus tidswelli (Cestoda: Proteocephalidea). Zeitschrift für Parasitenkunde, 64, 95-111.

Wiley, E.O., Siegel-Causey, D., Brooks, D.R. \& Funk, V.A. (1991) The compleat cladist a primer of phylogenetic procedures. Special Publication 19. Lawrence, Kansas: University of Kansas Museum of Natural History, $158 \mathrm{pp}$.

Willemse, J.J. (1968) Proteocephalus filicollis (Rudolphi, 1802) and Proteocephalus ambiguus (Dujardin, 1845), two hitherto confused species of cestodes. Journal of Helminthology, 42 395-410.

Willemse, J.J. (1969) The Genus Proteocephalus in the Netherlands. Journal of Helminthology, 43, 207-222.

Woodland, W.N.F. (1933a) On a new subfamily of Proteocephalid cestodes - the Othinoscolecinae - from the Amazon Siluroid fish Platystomatichthys sturio (Kner). Parasitology, 25, 491-500. 
Woodland, W.N.F. (1933b) On the anatomy of some fish cestodes described by Diesing from the Amazon. Quarterly Journal of Microscopical Science, 76, 175-208.

Woodland, W.N.F. (1933c) On two new cestodes from the Amazon siluroid fish Brachyplatystoma vaillanti Cuv. and Val. Parasitology, 25, 485-490.

Woodland, W.N.F. (1934a) On the Amphilaphorchidinae, a new subfamily of Proteocephalid cestodes, and Myzophorus admonticellia, gen. and sp. n., parasitic in Pirinampus spp. from the Amazon. Parasitology, 26, 141-149.

Woodland, W.N.F. (1934b) On some remarkable new cestodes from the Amazon siluroid fish, Brachyplatystoma filamentosum (Lichtenstein). Parasitology, 26, 268-277.
Woodland, W.N.F. (1934c) On six new Cestodes from Amazon Fishes. Proceedings of the Zoological Society London, 104, $33-44$.

Woodland, W.N.F. (1935a) Additional cestodes from the Amazon siluroids Pirarará, Dorad and Sudobim. Proceedings of the Zoological Society London, 104, 851-862.

Woodland, W.N.F. (1935b) Some more remarkable cestodes from Amazon siluroids fish. Parasitology, 27, 207-225.

Woodland, W.N.F. (1935 c) Some new proteocephalids and a ptychobothriid (Cestoda) from the Amazon. Proceedings of the Zoological Society of London, 105, 619-623. 